\title{
The Pitcairn hotspot in the South Pacific: distribution and composition of submarine volcanic sequences
}

\author{
R. Hekinian $^{a^{*}}$, J. L. Cheminée ${ }^{b}$, J. Dubois ${ }^{b}$, P. Stoffers ${ }^{a}$, S. Scott ${ }^{c}$, C. Guivel $^{d}$, \\ D. Garbe-Schönberg ${ }^{a}$, C. Devey ${ }^{e}$, B. Bourdon ${ }^{b}$, K. Lackschewitz ${ }^{e}$, G. McMurtry ${ }^{f}$ \\ and E. Le Drezen ${ }^{g}$
}

\begin{abstract}
${ }^{\mathrm{a} U n i v e r s i t a ̈ t ~ K i e l, ~ I n s t i t u t ~ f u ̈ r ~ G e o w i s s e n s c h a f t e n, ~ O l s h a u s e n t r a ß e ~ 40, ~ 24098, ~ K i e l, ~ G e r m a n y ~}$
${ }^{b}$ Institut de Physique du Globe de Paris, 4 Place Jussieu, 75252, Paris, France

${ }^{c}$ Geology Department, University of Toronto, Toronto, ON, Canada M5S 3B1

'Université de Nantes, Faculté des Sciences, 2 Rue de la Houssinière, 92208, Nantes, France

eUniversity of Bremen, Geowissenschaften, Postfach 340440, 28334, Bremen, Germany

fUniversity of Hawaii, Department of Oceanography, 1000 Pope Road, Honolulu, HI 96822, USA

${ }^{g}$ IFREMER Centre de Brest, Géoscience Marine, 29280, Plouzané, France
\end{abstract}

*: Corresponding author : Present address: Keryunan, 29290 Saint Renan, France. Tel./Fax: +33-2-98-84-99-53 hekinian@wanadoo.fr

\begin{abstract}
:
Multibeam bathymetry and bottom imaging (Simrad EM12D) studies on an area of about $9500 \mathrm{~km} 2$ were conducted over the Pitcairn hotspot near $25^{\circ} 10^{\prime} \mathrm{S}, 129^{\circ} 20^{\prime} \mathrm{W}$. In addition, 15 dives with the Nautile submersible enabled us to obtain ground-true observations and to sample volcanic structures on the ancient ocean crust of the Farallon Plate at 3500-4300 m depths. More than 100 submarine volcanoes overprint the ancient crust and are divided according to their size into large $(>2000 \mathrm{~m}$ in height), intermediate (500-2000 $\mathrm{m}$ high) and small ( $<500 \mathrm{~m}$ high) edifices. The interpretation of seafloor backscatter imagery accompanied by submersible observations and sampling enabled us to infer that the total volume of submarine lava erupted during hotspot activity is about $5900 \mathrm{~km} 3$ within a radius of about $110 \mathrm{~km}$. The most recent volcanic activities occur on both small and large edifices composed of a great variety of lava flows. These flows vary in composition, following a succession from picritic basalt to alkali basalt, trachybasalt, trachy-andesite and to trachyte. Their large range of $\mathrm{SiO} 2(48-62 \%), \mathrm{Na} 2 \mathrm{O}+\mathrm{K} 2 \mathrm{O}$ (2-11\%), Ba (300-1300 ppm), MgO (1-11\%), Nb (19-130 ppm), Ni (4$400 \mathrm{ppm}$ ) and rare earth elements suggests that crystal-liquid fractionation from basanite and/or picritic melt sources was a major process. The variation in composition between the least evolved basaltic rocks and the other more evolved silicic lava is marked by a difference in their flow morphology (pillow, giant tubes, tabular to blocky flows). The lava composition and field observation indicate that several magmatic pulses giving rise to cyclic eruptions are responsible for the construction of the edifices. The two larger edifices ( $>2000 \mathrm{~m}$ high) show more extensive eruptive events and a wider range in compositional variability than the smaller $(<500 \mathrm{~m}$ high) ones. Several (five) submersible transects made along the slope of one of the largest edifices (Bounty) enabled us to observe at least nine successive eruptive cycles progressing from pillow and giant tubular basalt to tabular/blocky trachy-andesite and trachyte flows. Pyroclasts and hyaloclastites are often found with these eruptive sequences. The smaller edifices, forming individualized cones, are built mainly of evolved silicic (SiO2>53\%) flows consisting essentially of alternating sequences of trachy-andesite and trachyte. The distribution and composition of the small edifices suggest that they are the result of sub-crustal forceful magma injection and channeling supplied from reservoirs associated with the large volcanoes.
\end{abstract}

Keywords: hotspot; volcanism; morphology; volcanic sequences; petrology 


\section{Introduction}

The Pitcairn hotspot is located on the southeastern extension of the Duke of Gloucester-Mururoa-Gambier-Pitcairn volcanic alignment (Fig. 1a). Hotspot volcanism began on the old Farallon plate on a crust of about 25 million years old. The Pitcairn region is one of five hotspots including the Society, Hawaii, Austral and Rockny Volcano of the Samoa Island chain, (Johnson, 1984) or perhaps six hotspots with the Louisville chain (Lonsdale, 1988) which are known to be volcanically active in the Pacific. The volcanoes that form the Pitcairn hotspot which is located about $80 \mathrm{~km}$ east of the Island of Pitcairn in a previously uncharted region of the South Pacific ocean near $25^{\circ} 20^{\prime} \mathrm{S}$ and $129^{\circ} 19^{\prime} \mathrm{W}$, were discovered during the 1989 cruise of the R.V. SONNE (leg SO 65) (Stoffers et al., 1989). Morphological and structural interpretations have previously been described by Stoffers et al. (1989) and Binard et al. (1992). The main results of these investigations have been to establish the ancient structural lineations (fissures and fractures) responsible for magma upwelling during recent hotspot volcanism. Woodhead and Devey (1993) and Ackermand et al. (1998) have reported the geochemical and petrological investigations of the volcanic rocks. The island of Pitcairn, rising $347 \mathrm{~m}$ above the sea floor, was previously described by Carter (1967) as being composed of basalt and evolved lava of trachytic composition. Pitcairn Island consists of a semi-circular tuff-ring caldera constructed during a hydromagmatic phase giving rise to important pyroclastic deposits (Binard et al., 1992). The apparent age of the surface lavas from Pitcairn Island is between 0.45 and about 1 million years (Duncan et al., 1974; Woodhead and McCulloch, 1989; Devey et al., 2002). Sr, Nd and Pb isotopic data (Woodhead and McCulloch, 1989) from the Pitcairn Island formations suggested the partial melting of two primary magma components: one consisting of oceanic crust with a small proportion of sediment and the other one made of altered oceanic crust. Also from Pitcairn lavas, the variation in $\partial^{18} \mathrm{O}$ (Woodhead et al., 1993) indicates that mixing between oceanic crust and plume magma may have prevailed during the diapiric ascent of a mantle plume.

The Polynaut cruise conducted with the N.O. L'ATALANTE and the submersible NAUTILE (22/8/1999-20/9/1999), was designed to investigate the geodynamic and volcanic setting of three hotspot regions: Society, Macdonald (Austral) and Pitcairn hotspots (Figure 1a). During this cruise, most of the studies focused on the Pitcairn hotspot (14 of the 21 dives) (Table 1). Also, 13 dredges and 14 hydrological stations (CTD) were performed. The present work deals primarily with the geomorphology of the seafloor and the composition of the erupted lava on the various size edifices within the Pitcairn hotspot. The work is based on data obtained during a multibeam (SIMRAD EM12D) bathymetry and seafloor backscatter imagery survey combined with field observations with the submersible NAUTILE which were carried out during the cruise. To complete our data, deep-towed observations and sample stations obtained during a previous cruise (RV SONNE, leg 65) have also been used.

One of the major objectives of this work is to define the boundary of the Pitcairn hotspot activity and to infer the volcanic budget associated with the hotspot. Because of the difficulty of acquiring extended and continuous observations of oceanic outcrops, very little is known about the volcanic stratigraphy of submarine volcanoes. During the Polynaut cruise, special effort was made to conduct detailed geological observations along several dive profiles covering transects from the bottom to the top of the volcanoes. The present work attempts to reconstruct the stratigraphy of the volcanic sequences as observed along some of the best-documented profiles as far as sampling and observations are concerned. This is done in order to show the cyclic nature of the volcanic events responsible for building the edifices using lava morphology and the rocks' compositional variability. The questions that we tried to answer are: What is the extent of the hotspot activity? Is there any magmatic and morphostructural relationship between the various types of volcanic constructions? 


\section{Morpho-structural setting}

In intraplate regions it is often difficult to distinguish between structures caused by hotspot volcanism from those inherited from crustal accretion at spreading ridges. The criteria used here to differentiate between ancient and newly formed crust is primarily based on surface morphology and structural lineations obtained from (SIMRAD EM12D) sea floor imagery and field observations. The total bathymetry coverage comprised about $9500 \mathrm{~km}^{2}$ of which about $7022 \mathrm{~km}^{2}$ are interpreted as being volcanic cones produced by intraplate volcanism on the Pitcairn region (Fig.1b, 2a and 2b). The most prominent feature of the Pitcairn hotspot is the high density of the volcanic cones. The total number of volcanic cones is about ninety with most being less than $500 \mathrm{~m}$ in height. About 10 submarine edifices vary from intermediate (> $500-2000 \mathrm{~m}$ high) to large (> $2000 \mathrm{~m}$ high) sizes. Also, the deeper area (> 3800) located south of latitude $25^{\circ} 25^{\prime}$ 'S has fewer volcanic constructions and lower relief. Most of the submarine edifices are concentrated in the central and northern part (north of $25^{\circ} 25^{\prime} \mathrm{S}$ ) of the surveyed area at less than $3500 \mathrm{~m}$ depth (Fig. 1b).

The remaining major structures marked by faults, fissures, fractures and linear ridge segments are ancient constructions inherited from the Farallon plate. The main structural orientations are $\mathrm{N}-\mathrm{S}\left(\mathrm{N} 160^{\circ}\right)$ and $\mathrm{N} 055^{\circ}$, the former representing traces of ancient crustal/lithospheric ridge-parallel horst-graben structure and the latter with the traces of oblique pseudo-fault-like alignments (Fig. 1b, 2a and 2b). The pseudo-faults are comparable to those associated with modern spreading ridge propagators (e.g. Naar and Hey, 1991; Batiza, 1996 and others).

\subsection{Seafloor back-scatter imagery}

The back-scattered acoustic signal reflecting on the seafloor gives an image that depends on the nature of the material encountered (Fig. 2a). Darker areas represent seafloor with high acoustic impedence such as a volcanic basement. Steep slopes, faults and fissures show up as linear dark gray features. In order to interpret the image obtained with the SIMRAD EM12D system, we used dive data as well as previous deep towed bottom camera observations (Stoffers et al., 1990; Binard et al., 1992). About 26\% of the surveyed region (south of $25^{\circ} \mathrm{S}$ ) is covered mainly with sediment (>50\%) intermixed with volcanoclastic $(<15 \%)$ debris (silt and sand size) having the lowest reflectivity (LR). Fe-Mn oxyhydroxide rich sediment (e.g. dredge station D15 on an old spreading ridge) was found to be associated with the sedimented terrain covering the old propagating ridge (Fig.2a and 2b). Also during dives PN7 and PN10 (> $3700 \mathrm{~m}$ depth), sedimented seafloor with cobble and sand sized pyroclastic debris $(<15 \%)$ was observed. The structures with LR are inherited from the ancient crust of the Farallon plate, now almost totally covered by sediment and ash (e.g. spreading ridge and small axial and off-axial volcanoes in Fig. 2a and 2b). The next darker area has lower amounts (20-40\%) of sediment cover with volcanoclastic debris and a hilly topography of low relief (Fig. 2a and 2b). These features consist of pillows, lava tubes and blocky-tabular flows, loose talus material as well as Fe-Mn oxyhydroxide enriched hydrothemal sediment and crust (e.g. dredge station D10, volcano \# 7 and Young) (Fig. 1b, 2a and $2 \mathrm{~b}$ ). This area is called "patchy" (P) because of the appearance of light-gray streaks and a hummocky surface reflectivity. This "patchy" area comprising about $24 \%$ of the surveyed region is found essentially surrounding the large and the intermediate (\# 7, Young, Christian, McCoy and Di) or small volcanoes (Fig. 2a and 2b). Poorly consolidated and fragmented material such as talus debris, volcanoclasts and hyaloclasts were observed during the dives (e.g. PN13, PN1 and PN8) and deep towed camera stations (SO65, OFOS78, Binard et al., 1992) in these patchy areas (Table 1, Fig. 1b, 2a, 2b, and 5f). Bulbous and giant tubular flows 
are partially buried by sediment (about 20-25\%). Although the patchy (P) area has a relatively middle to low-reflectivity, it is considered to have mainly formed during hotspot activity, with the exception of the intermediate size volcanoes, (\# 7, Young, Christian and McCoy) whose origin is uncertain. A middle level reflectivity (MR) is seen in about $26 \%$ of the explored area and essentially includes the deeper (> $3500 \mathrm{~m}$ depth) volcanic landscape. The MR comprises areas having a smooth surface, a large wavelength topography and small constructional edifices ( $<300 \mathrm{~m}$ high) (Fig. 2a and 2b). Moderately fresh silicic lavas were sampled (e.g. small volcano at dredge site D11) (Fig. 1b, 2a and 2b). The darker gray area, having a middlehigh reflectivity (MHR) comprising about $4 \%$ of the surveyed zone, is mainly on the flanks of the most recent edifices such as the Bounty and Adams volcanoes. These are essentially made of bulbous pillows, giant tubular and blocky/tabular and scoriaceous flows, hyaloclastite crust and pyroclastic material. Their structures differ from those in other areas with MR and P reflectivity by their relatively low sediment distribution $(<20 \%)$ and the presence of star shaped ridges (rift zones) with sharp near vertical breaks representing flow fronts. The darkest area corresponds to the zone of highest reflectivity (HR) comprised of fresh volcanics with less than $5 \%$ sediment, most of which is of hydrothermal origin. The HR area covers about $20 \%$ of the explored hotspot region and is associated with small volcanic cones (e.g. site of dredge D3) (Fig.1b, 2a and 2b). Deep (3600-4000 m depth) depressions associated with fault scarps including a graben-like structure occur mainly in the western area near the ridge propagator and pseudo-fault zone (Fig. 2a and 2b). These HR topographic lows with little relief and few small volcanic cones are probably the sites of relatively young fissural eruptions giving rise to lava ponds (Fig. 1a, 2a and 2b). The HR occurs also in areas with hummocky (patchy, P) appearance such as along the rift zone of the Bounty and Adams volcanoes, and area near the \# 7 and Young volcanoes (Fig. 2a and 2b). For example, at the western extremity of \# 7 volcano, there is a small cone with high reflectivity (HR) suggesting recent volcanism (Fig. 2a and 2b). Hence, the areas around \# 7 and Young volcanoes showing both low (LR) and high (HR) sea-floor reflectivity could have been sites of hotspot rejuvenation.

\subsection{Size and volume of hotspot edifices}

In order to evaluate the submarine activity on the various morpho-structural provinces observed in the Pitcairn Hotspot region, we used both bathymetry and bottom imaging systems to classify the volcanic edifices (Table 2). In addition, as interpreted on the basis of seafloor backscatter imagery, the morphology of the sea floor at 3500-3800 m depth contour lines surrounding these edifices was considered separately in order to define the limits of the hotspot activity at a distance from the large edifices (Table 2).

\subsubsection{The large edifices}

The larger submarine volcanoes, Bounty and Adams, are less than $35 \mathrm{~km}$ apart from peak to peak and are similar to composite volcanoes (Davidson and Silva, 2000). The term "composite" is used here to describe edifices that underwent several stages of growth and are comprised of multiple cones, which formed during a short period of time with a limited amount of volcanism within a small area. The Bounty and Adams volcanoes with a mean slope of $15^{\circ}$ (Binard et al., 1992), are about 19 and $30 \mathrm{~km}$ in basal diameter, $3.5 \mathrm{~km}$ high, and have erupted a volume of about $310 \mathrm{~km}^{3}$ and $858 \mathrm{~km}^{3}$ of lava respectively. These volcanoes were built during multiple events comprising different types of lava flows and volcanoclastic products. Smaller cones and lava mounds (hornitos, hay-stacks) also occur along rift zones as well as flow front features with almost vertical walls of lava tubes oriented down-slope. 


\subsubsection{The intermediate edifices}

The intermediate size volcanoes explored include volcanoes \# 4, \# 7, Young, Di, and Christian. These five edifices of intermediate size (5 -10 km in diameter, $>0.5-2 \mathrm{~km}$ high) have erupted at least $159 \mathrm{~km}^{3}$ of lava (Table 2). A previous study (Binard et al., 1992) described the general morpho-structural aspect of the first four edifices. Based on their degree of flatness (summit diameter/basal diameter $>22^{\circ}$, Binard et al., 1992), the flat topped volcanoes and collapsed crater (Young and \# 7) were inferred to represent ancient off-axial edifices of the Farallon plate. This is corroborated by the presence of altered MORBs (Binard et al., 1992; Woodhead and Devey, 1993) (Table 1, Fig. 1b and 2b). However, as mentioned above, the sonar data also showing small areas of high (HR) and medium (MR and P) reflectivity around Young and \# 7 edifices, might suggest the presence of younger flows having a hotspot origin (Fig. 1b, 2a and 2b, Table 1). Christian volcano (10 km in diameter and $2 \mathrm{~km}$ in height) has a small adventive cone located on its northern flank, and consists of altered T-MORB rocks (dredged D7, Table 1, Fig. 1a and 1b). Di volcano, south of Adams within the $3500 \mathrm{~m}$ contour line, has a conical shape with hummocky terrain (P reflectivity) and has erupted trachybasalt (dredge D5) (Table 1, Fig. 1a, 2a and 2b).

\subsubsection{The small edifices}

The smallest volcanoes, are about $2 \mathrm{~km}$ in diameter and less than $<0.5 \mathrm{~km}$ high. These small edifices are also the most abundant (with a total of about 90) that together have erupted a total of about $47 \mathrm{~km}^{3}$ of volcanic rocks (Table 2). The small edifices found at a distance of 5 - $35 \mathrm{~km}$ from the base of the larger volcanoes are generally aligned along two main directions, $\mathrm{N}-\mathrm{S}\left(\mathrm{N} 160^{\circ}\right)$ and $\mathrm{NW} 55^{\circ}$. Other small edifices can also be found as adventive cones on the flanks and in the immediate surroundings less than $5 \mathrm{~km}$ away from the base of the large volcanoes (Fig. $1 \mathrm{~b}$ and $2 \mathrm{~b}$ ).

\subsubsection{Sea floor hotspot activity at 3500-3800 depth}

The sea floor surrounding most of the volcanic edifices is built on 30 Ma old oceanic crust. At that age, the depth of the sea floor crust is theoretically estimated to be at about 4300 $\mathrm{m}$ depth (Parson and Sclater, 1977). The observed sea floor mean depth of the Pitcairn region is about 3750-3800 m (Binard et al. 1992) (Fig. 1b). From our present survey based on diving and sampling, it was observed that most of the deepest area (3800-4200 m depth) is heavily sedimented with occasional MnOx coated partially buried pillows. In addition, the volcanic constructions and most areas having high back-scattered reflectivity (HR, MHR and most P and MR) occur at depths shallower than $3800 \mathrm{~m}$ depth (Fig. 1a, 2a, 2b).

In order to evaluate the volume and extent of hotspot activity, it is assumed that the base of the ancient oceanic crust constructed on the Farallon plate, lies near the 3800 meter contour line. This excludes the larger edifices (e.g. Christian, Young and \# 7) which are presumed to have formed near and/or on spreading ridges. Thus, it is found that the volume of the submarine hotspot volcanism covering the area (at 3500-3800 m depth) with high (HR), patchy (P), middle (MR) and middle-high (MH) reflectivity comprises about $3581 \mathrm{~km}^{3}$ or $5907 \mathrm{~km}^{3}$ of volcanics when including Pitcairn Island itself.(Table 2).

The age of the Pitcairn Island has been determined to be between $0.4-1$ million years (Duncan et al., 1974; Woodhead and McCulloch, 1989). Guillou et al., (1997) made K/Ar age determination on three samples from the Bounty (1889 $\mathrm{m}$ depth) and from the Adams (516 m depth) volcanoes. His studies revealed ages of $344 \pm 32$ and $3 \pm 1$ kilo-years, respectively. Recent hydrothermal activities and fresh lava flows observed during submersible dives indicate that the Bounty volcano is presently active. Also, recent volcanic 
events invading older flows with some interstitial sediment are observed along dive tracks (PN14 at depth of $1851 \mathrm{~m}$ ) on the same edifice (Table 1, Fig. 1b). In addition, the presence of small cones and mounds along the slope of the large edifices (Adams and Bounty) suggests that flank eruptions are still taking place along preferential rift zones. Indeed, steep scarps (near vertical) up to 20-40 meters high with fresh lava, which may represent flow fronts, are observed.

It is assumed that the farthest eastern limit of the hot spot is now located near the Bounty and Adams volcano, at approximately $110 \mathrm{~km}$ east of Pitcairn Island, and that the spreading rate for the oceanic plate's motion is about $80-10 \mathrm{~mm}$ per year. Therefore, the age of the early volcanism forming the Pitcairn Island, calculated on these two assumptions, probably occurred 1.1 million years ago. The $5907 \mathrm{~km}^{3}$ volume of volcanic construction over 1.1 million years gives a volcanic accumulation rate of about $0.0054 \mathrm{~km}^{3} / \mathrm{yr}$. This value is about 20-33 times less than that of the Kilauea volcano in Hawaii (0.1-0.18 $\mathrm{km}^{3} / \mathrm{yr}$ ) (Clague et al., 2000, Cayol et al., 2000). The construction of a large edifice such as the Bounty volcano (3500 m high) with about $310 \mathrm{~km}^{3}$ of lava will have taken place in about 58,000 years.

\section{Rock composition and morphology}

The individual edifices formed during focused volcanism are characterized by a large variety of volcanic products commonly erupted on a single volcano. The most striking volcanic feature observed in the Pitcairn area is the wide distribution of volcanoclastic material. Typically this is loose (boulder to sand size) material intermixed with brownish and light-gray pelagic sediment. The volcanoclastic deposits are of both pyroclastic (Fisher 1966) and hyaloclastic origin. The pyroclasts are fragments of various sizes (boulders, lapilli, sand and silt size) ejected during explosive eruptions and forming a poorly sorted sequence of thin ash and accidental rock debris. For example, highly vesicular lapilli of trachy-andesite (PN1303) mixed with Fe-Mn oxyhydroxide rich sediment were found on a small volcanic cone (Table 1). Also, the hyaloclastites form slabs about 10-15 cm thick (e.g. PN13-05) made up of moderately indurate sediment (silty-clay), light-brown Fe-Mn hydroxide, glassy shards and small scoria fragments. The hyaloclastites cover the lava flows on the slope and top of the volcanic edifices (PN13-06, Table 1). On the other hand, these volcanoclasts are also found in association with pelagic sediment blanketing the seafloor around the volcanoes. They patchy distributions around and/or on the edifices are interpreted to be the result of explosive eruptions taking place at less than $3500 \mathrm{~m}$ depth.

Generally, the hotspot lavas differ from EPR spreading ridge volcanics in their greater content of vesicles. The degree of vesicularity in pillow lava and other types of flows varies from moderate ( $<10-25 \%$ vesicles) to high ( $>30 \%$ vesicles and up to $65-70 \%$ in volume). Although no detailed analyses on $\mathrm{H}_{2} \mathrm{O}$ and carbon are presented, the volatile content of the Pitcairn hotspot basaltic rocks obtained from routine (lost on ignition =LOI of $0.1-3.4 \%$ ) analyses show a higher variation range than that of MORBs (Table 3). The extrusive flows were classified into separate categories according to their mineral associations, composition and morphology. The mafic and least evolved lava consists essentially of alkali basalt and picritic basalt with more than 7\% olivine in their glassy matrix. The geochemistry of previously dredged basalts documented elsewhere (Devey et al., 1993; Stoffers et al., 1989; Woodhead and Devey, 1993; Ackermand et al., 1998) are used here (Fig. 3a). Based on major element, trace element and REE distributions, several types of basalt are recognized:

1) The picritic alkali basalts (3-04, -05, -09, 10, -11) are essentially pillow lavas and contain 7$15 \%$ of early-formed olivine and spinel. They have high values of Ni (300-500 ppm) and 
MgO (10 - 13\%, bulk), low $\mathrm{SiO}_{2}$ (46-47\%), and $\mathrm{Ba}(160-300 \mathrm{ppm})$, and their $\mathrm{Zr}$ (200-300 $\mathrm{ppm}), \mathrm{K} / \mathrm{Ti}(>0.6), \mathrm{Zr} / \mathrm{Y}(9-11), \mathrm{Nb} / \mathrm{Y}(0.8-1)$ and $(\mathrm{La} / \mathrm{Sm})_{\mathrm{N}}(2-3)$ values are similar to the alkali basalts (Table 3 and 4, Fig. 3a, 3b, and 4c). Differences between the bulk analyses of these porphyritic lava and their glassy margin are due to the presence of olivine phenocrysts (i.e. 3-05 and 3-11, Table 3 and 4).

2a) Alkali basalts are enriched in $\mathrm{Na}_{2} \mathrm{O}+\mathrm{K}_{2} \mathrm{O}$ (3.5-6\%) and $\mathrm{Ba}(250-400$ ppm) contents. They have moderate $\mathrm{Ni}$ (30-100), Zr (230-300 ppm), $\mathrm{K}_{2} \mathrm{O}$ (1 - 1.7\%), K/Ti (>0.6), Zr/Y (9 - 11), $\mathrm{Nb} / \mathrm{Y}(0.8-1.5)$ and $(\mathrm{La} / \mathrm{Sm})_{\mathrm{N}}(2-3)$, comparable to picritic basalt) values (Table, 3, Fig. 3a, 3b and 3c,). They mainly form pillow lava and giant tubes with well developed radial jointings (Fig. 4a, 4d and 4f).

2b) Sub-alkali basalt (9-01, $-10,-12$ and D6-01) from the Adams volcano are relatively depleted in $\mathrm{Na}_{2} \mathrm{O}+\mathrm{K}_{2} \mathrm{O}(3-4.2 \%),(\mathrm{Ba}=140-230 \mathrm{ppm}) \mathrm{K}_{2} \mathrm{O}(<1 \%)$ and $\mathrm{K} / \mathrm{Ti}(0.3-0.4), \mathrm{Zr} / \mathrm{Y}(7-9)$, and $\mathrm{Nb} / \mathrm{Y}(0.8-1)$ values when compared to the other alkali basalts (Tables, 3 and 4, Fig. 3a and 3c). However, the REE content of these latter samples are similar to that of the alkali basalts (Table 3). They are close in composition to the E-MORBs from which they differ by their higher degree of vesicularity $(>15 \%)$, higher $\mathrm{Zr} / \mathrm{Y}$ and $(\mathrm{La} / \mathrm{Sm})_{\mathrm{N}}$ ratios.

3) T-MORBs (80DS2, D7-02) have low K/Ti (0.12-0.25\%), $\mathrm{Na}_{2} \mathrm{O}+\mathrm{K}_{2} \mathrm{O}(<3 \%), \mathrm{Zr}$ $(<200 \mathrm{ppm}), \mathrm{Ba}(23 \mathrm{ppm}), \mathrm{Zr} / \mathrm{Y}(2-3) \mathrm{Nb} / \mathrm{Y}(<0.2)$ and $(\mathrm{La} / \mathrm{Sm})_{\mathrm{N}}(0.4)$ values (Table, 3 and 4$)$.

The main differences between sub-alkali and the more enriched alkali basalts are in their incompatible element contents, although lava morphologies are similar and both are vesicular (15-20\% vesicles). The most depleted (T-MORB) samples (D7-02 and 80DS) collected from a small adventive cone on the northern flank of the Christian volcano and from Young (Table 3, and Fig. 1b) consist of altered pillow lava fragments with palagonatized glassy margins and Fe-Mn oxyhydroxide crusts $<5 \mathrm{~mm}$ thick. These MORBs are interpreted to have formed during pre-hotspot volcanism on the ancient Farallon plate.

The silicic lavas have variable morphology and are mainly characterized by thick (5 $20 \mathrm{~cm}$ thick) glassy aphyric margins with large cavities (1-2 cm long). Some surfaces appear scoriaceous due to the agglutination of welded glassy rinds. Most of these flows are blocky, tabular and/or form giant tubes with flattened surface (Fig. 5a and 5b). Based on their surface morphology and compositions, the silicic lava are divided into:

1) Trachybasalts that consist essentially of pillow lava having typical radial jointing with $\mathrm{SiO}_{2}$ (49 - 53\%), $\mathrm{Na}_{2} \mathrm{O}+\mathrm{K}_{2} \mathrm{O}$ (4 - 8\%), Ba (300-800 ppm), $\mathrm{Ni}(<100 \mathrm{ppm})$ $\mathrm{Zr}=300-500 \mathrm{ppm}, \mathrm{Zr} / \mathrm{Y}(10-13), \mathrm{Nb} / \mathrm{Y}(1-1.6)(\mathrm{La} / \mathrm{Sm})_{\mathrm{N}}(2-3)$ and $\mathrm{Ni}(4-$ 100 ppm) ((Tables 3, 4 and 5 and Fig. 3a, 3b, 3c, 3d and 3f).

2) Trachy-andesites that occur mostly as blocky/tabular and flattened giant tubular flows (Fig. $5 \mathrm{~g}$ and $5 \mathrm{~h}$ ). They are characterized by relatively high values of $\mathrm{SiO}_{2}$ (53 - 59\%), $\mathrm{Na}_{2} \mathrm{O}+\mathrm{K}_{2} \mathrm{O}$ (4-8\%), Ba (500-1000 ppm), Zr/Y (9 - 15), Nb/Y (1.08 2) $(\mathrm{La} / \mathrm{Sm})_{\mathrm{N}}(2.3$ - 4.5) and $\mathrm{Zr}(400$ - $800 \mathrm{ppm})$ (Tables, 3- 5)).

3) Trachytes are essentially light gray aphyric tabular and blocky flows with elongated vesicles (Fig. 5a, and 5b). Their glassy matrix contains microlites of plagioclase laths and has a fluidal texture. They have the highest $\mathrm{SiO}_{2}(59-$ 64\%), $\mathrm{Na}_{2} \mathrm{O}+\mathrm{K}_{2} \mathrm{O}$ (> 8\%), $\mathrm{Ba}(>1000 \mathrm{ppm}), \mathrm{Zr} / \mathrm{Y}(>15), \mathrm{Nb} / \mathrm{Y}(1.6-2.5)$, $(\mathrm{La} / \mathrm{Sm})_{\mathrm{N}}(3-6)$ and $\mathrm{Zr}(>700 \mathrm{ppm})$ values (Tables 3, 4 and 5 and Fig. 3a, 3b, 3c, and 3f).

The trachytes and the trachy-andesites are the most depleted in $\mathrm{Ni}(<1 \mathrm{ppm})$ and $\mathrm{MgO}$ $(<3 \%)$ (Tables, 3 and 4$)$. Modelling for a liquid line of descent show that the fractional crystallization of basanite (SO65-41DS1, Hekinian et al., 1989) and/or picritic basalt parents (3- 05, Table 3) could produce the alkali basalt-trachyte suites (Fig. 3a and 3b). Also, the 
distinct $\mathrm{K} / \mathrm{Ti},(\mathrm{La} / \mathrm{Sm})_{\mathrm{N}}, \mathrm{Nb} / \mathrm{Y}$ and $\mathrm{Zr} / \mathrm{Y}$ ratios between the sub-alkali basalt, alkali basalt, and MORBs $(<0.25,<0.2$ and $<1$ respectively) suggest that they are issued from different parental mantle sources having a varying extent of partial melting (Fig. 3c and 3d). In addition, it is also observed that most smaller and intermediate size edifices generally contain more evolved lavas such as trachy-andesites to trachytes than do the larger edifices. This is shown by the higher MgO (4 - 12\%) and lower total alkali $(<5 \%)$ and $\mathrm{SiO}_{2}(<52 \%)$ contents of the large edifices with respect to those of small and intermediate sizes (Table 3 and 4, Fig. 3b). It is observed that some small adventive cones formed on the large edifices (Adams and Bounty) contain alkali basalt rather than silicic flows (Fig. 6b). Also, silicic flows from other small ( 8-01, -03, -08, 7-01, D12, and D3) and intermediate (Di volcano, D5-01) edifices away from the large volcanoes show the same incompatible element $(\mathrm{La} / \mathrm{Sm})_{\mathrm{N}}(2-3)$ and $\mathrm{Nb} / \mathrm{Y}(0.9-1.5)$ ratios as the large edifices suggesting a similarity in source (Fig. 3c). In addition, there is a continuous trend of variability of compatible and incompatible elements indicating a similar magmatic history among the small and large edifices (Fig. 3b and 3c). Further study on the petrology of these volcanic rocks will be presented separately.

\section{Volcanic sequence}

Detailed geological observations along several profiles of large volcanic edifices such as Bounty (dives PN03, -06, -04, -12, and -14) were conducted in order to map the volcanic stratigraphy. Another dive (PN13) made on a small adventive cone located at the foot (3000 $\mathrm{m}$ depth) of Bounty is also reported here. Visual observation and lava composition have permitted us to map the stratigraphic sequences of the various volcanic units encountered along the slope of these two edifices (Bounty and dive site PN13). For this purpose, bottom camera and video captured images of various types of outcrop observed have been selected from these dives (Fig. 4a-4h and 5a-5h). The geology of the different lava flows is drawn on the profiles combining dive observations as well as dredge stations (Fig. 6a and 6b).

Sequential volcanic eruptions are shown by the repetitive nature (composition and lava morphology) of the volcanics encountered on the same edifice. The term "volcanic sequence" and "cyclicity" used here refer to compositional changes during eruption. Crystalliquid fractionation would suggest pyroclast and silicic lava should erupt prior to basalt. However, the presence of composite lava flows might suggest the opposite. In a conduit, less viscous mafic melt will ascend more rapidly and upon mixing with the silica rich melt this will facilitate its extrusion (Gibson and Walker 1963; Yoder, 1973). As differentiation takes place, volatiles will concentrate in the higher level of the reservoir. Also, this will lower the melt's density and facilitate the extrusion of evolved melt. In order to discuss and visualize the volcanic sequences, we have arbitrarily decided that the first erupted flow is usually picritic basalt and alkali basalt followed by trachybasalt and terminating with more viscous lava such as trachy-andesite and trachyte (Fig. 6a and 6b). The evidence of sequential volcanism is demonstrated by the superposition of individual flows erupted in a relatively short period of time. These various volcanic units are observed on steep scarps (flow fronts), fault scarps and as thin sub-horizontal layered flows. Exposed lava units have different morphologies such as sections of radial pillows overlain by more blocky and tabular lava commonly having quite a different composition (Fig. 5h and 6b). Some dull-looking flows are partially covered by more recent glassy flows (PN3-03) (Fig. 4b). Occasionally, basaltic flows form small (<20 m high) and rootless mounds (e.g. (haystacks and hornitos) supplied by short tubular lava-channels along the gentle slopes of the edifice (Fig. 4e, 4g, and 6a). The least evolved lava occurs essentially as pillows and giant tubes (Fig. 4a, 4c, 4d and 4f) while more viscous evolved lavas (trachy-andesite and trachyte) form flattened tubes and mainly 
tabular blocks with thick (up to 10 - $20 \mathrm{~cm}$ thick) glassy crusts (Fig. 5a, 5b and 5e). These flows commonly have a scoria-like surface due to cracking of the outer crust, followed by melt spill and quenching during drainage of the lava tubes (Fig. 5d). Also they do not show radial joints but, rather, layered internal structure with elongated cavities (Fig. 5c, 5e, and 5g). The flow layering reflects the viscosity of the lava related to its composition (silica enriched). Fluidal arrangements of plagioclase laths and vesicles are common features with this type of morphology. During an eruption, pyroclasts and hyalocasts eventually mark the end of volcanic events of individual single edifices (Batiza, 1989; Hekinian et al., 2000). In the Pitcairn hotspot, the pyroclasts and hyaloclasts are usually associated with the evolved flows (Fig. 5f). For example, trachybasalt 14-06 was found on top of a scarp near a flat area covered with a dark ash deposit at $1421 \mathrm{~m}$ depth on Bounty volcano. Overlying ash and hydrothermal sediment-filling cavities between pillow flows were also seen at $952 \mathrm{~m}$ during dive PN14 (Fig. 4h).

Along the dive profiles, reconstructed on the western flank of Bounty volcano, at least nine volcanic sequences (units) have been recognized. Each of these units varies by about 300 $\mathrm{m}$ in average thickness and comprises different types of flows (Fig. 6b). A schematic representation of compositional and morphological sequences based primarily on observations made on Bounty is shown on Figure 6a and Table 5. The other profile (PN13), along the southern slope of a small adventive cone located near the base of Bounty, consists of at least four sequential units of less than $300 \mathrm{~m}$ thick (Fig. 6b). In contrast with the other sequential units, the ones along the adventive cone, consist essentially of trachy-andesite, trachyte and pyroclast/hyaloclast associations (Table 1). Unfortunately, due to the lack of continuous data (observations, and sampling) during all the submersible dives, it was not possible to reconstruct the geology along all the dive profiles. Nevertheless, on the large volcanoes,using samples recovered from dredge hauls and sporadic sampling during dives, it is observed that the composition of both evolved (trachybasalt to trachy-andesite) and less evolved alkali basalt are found at all depths (Fig. 1b, and Table 1). This observation has reinforced the idea for the existence of sequential volcanism on other edifices.

In summary, the observed sequential diversities of the exposed lava are related to individualized volcanic pulses taking place on the flanks and the summits of the volcanoes. It is likely that the individual flows, during each volcanic cycle, have extended for a relatively short distance $(<300 \mathrm{~m})$ when compared to subaerial eruptions. This is due to the limited extent of magma delivery and to the seafloor environment (seawater pressure and quick cooling of surface flows). The edifices of the Pitcairn hotspot have a relatively lower magmatic budget than most known subaerial active volcanoes (e.g. Hawaii).

\section{Relationship between volcanic edifices}

The relationships between the various volcanic edifices forming the Pitcairn hotspot are explained on the basis of the tectonic and compositional variation of the lavas. Hotspot volcanism is influenced by preexisting structural features in the lithosphere such as fracture zones, faults and fissures (Binard et al., 1992) or by weaknesses which are newly created by stresses during plate tectonic motions in oceanic basins. Models and concepts on the dynamics for propagating cracks and dike injections (Harrison, 1968; Turcotte, 1982; Lister and Kerr 1991), as well as examples of magma channeling in Iceland, Hawaii (Wilson et al., 1980; Sigurdsson, 1987; Rubin and Pollard, 1987; Embley and Chadwick, 1994; Smith, et al., 1994; Bower and Woods, 1997) and along spreading ridges (Michael et al.,1989; Dziak et al., 1995; Chadwick et al.,1995) are well documented. Experiments (Seyfried and Freundt, 2000) on basaltic conduit flow suggest that when a large volume of gas bubbles is released, it reaches high velocity, resulting in breaking up any cap rocks (obstacles). Hence, the pressure 
of silicic magma stored in a reservoir might increase as the result of the additional magma input and fractional crystallization with the accumulation of volatiles.

Taking these observations into consideration, we can make inferences on the construction and evolution of the smaller volcanoes with respect to the larger ones formed on the Pitcairn hotspot. In the Pitcairn area, the smaller edifices often show preferential directions that indicate the fault and fissure-propagating systems which could give rise to eruptive cones (Fig. 1b, 2a and 2b). A major difference between the different size edifices is related to their range in compositional variability and geological setting. Some of the small edifices are formed on the flanks of the larger volcanoes, while others are formed close to (< $5 \mathrm{~km}$ ) their bases (Fig. 1b, 2a and 2b). However, most of the small and intermediate edifices are located at some distance $(5-35 \mathrm{~km})$ from the base of larger volcanoes lying within the $3700 \mathrm{~m}$ isobath, and consist essentially of silicic lava (Table 3). Evidence for feeder channels and eruptions is inferred from the distribution of small edifices found along preferential tectonic directions $\left(\mathrm{N} 180^{\circ}, \mathrm{N} 160^{\circ}\right.$ and $\left.\mathrm{N} 055^{\circ}\right)$ away $(5-35 \mathrm{~km})$ from the larger edifices (Fig. $2 \mathrm{a}$ and $2 \mathrm{~b}$ ). Some of the edifices are aligned along elongated topographic highs emanating from the foot of the larger edifices (Adams and Bounty). The most obvious volcanic channels with at least $200 \mathrm{~m}$ relief with respect to the surrounding seafloor are observed to extend in a south-southwesterly $\left(25^{\circ} 15^{\prime} \mathrm{S}-120^{\circ} 30^{\prime} \mathrm{W}\right)$ and in a southern $\left(25^{\circ} 30^{\prime} \mathrm{S}-129^{\circ} 19^{\prime} \mathrm{W}\right)$ direction away from the Bounty and Adams volcanoes respectively. Elongated and bulging structures also occur up to about $20 \mathrm{~km}$ in length and 1 - $4 \mathrm{~km}$ wide with scattered small volcanic edifices erected along their length (Fig. $1 \mathrm{~b}$ and $2 \mathrm{~b}$ ). Other volcanic alignments (oriented $\left.\mathrm{N} 045^{\circ}-\mathrm{N}^{\circ} 5^{\circ}\right)$ in the north-east region $\left(25^{\circ} \mathrm{S}-129^{\circ} \mathrm{W}\right.$ and $\left.25^{\circ} 15^{\prime} \mathrm{S}-129^{\circ} 20^{\prime} \mathrm{W}\right)$ are represented by small edifices decreasing in basal depth (3200 m to $3500 \mathrm{~m}$ ) away (up to 30 $\mathrm{km}$ ) from the large edifices (Bounty and Adams) (Fig. 1b). The area of these small edifices also shows a relatively higher degree of reflectivity (HR, MHR and P) than the older, more heavily sedimented sea floor (LR) (Fig. 2a and 2b).

The volcanics erupted on the small edifices (adventive cones) or on the flanks of the larger edifices as well as those in their immediate vicinities ( $<5 \mathrm{~km}$ away from the base) are interpreted to have extruded from the same main feeder and/or melt reservoir as the large edifices. This is suggested by the basal $(<3500 \mathrm{~m}$ isobath) topographic continuity between the large and small edifices (Fig. 1b, 2b). The compositional continuity of both compatible and incompatible compounds of the various size edifices is suggestive of a common magmatic origin (Fig. 3b and 3c). These edifices might have tapped melts from the same magmatic reservoirs underneath the large edifices. Volcanism could occur on the summit and continue on the flank of the larger edifices. As a volcano grows, its mass will increase, raising the lithostatic pressure on the magma reservoir. As the height of the volcano increases, probably less magma will erupt from the summit and more from lateral vents, rift zones and parasitic cones. In order for the extrusive flow to continue, overcoming the lithostatic pressure, it is necessary for the magma reservoir to become more evolved as replenishment with new melts and crystal liquid fractionation take place. Evolved lavas (e.g. trachy-andesite and trachyte) such as those erupted in these small cones, are volatile enriched, less dense and viscous, and therefore more likely to overcome the load pressure as well as flow in subcrustal channels. Focused and episodic magma injections away from the large edifices in a cooler lithosphere will fractionate and give rise essentially to the extrusion of silicic lava, while basaltic melt will stay in the conduits. Solidification of magma will shut off the flow until a new fracture is formed, resulting in the episodic nature of surface eruptions. Thus, it is speculated that these small size edifices away from the large edifices are more inclined to erupt silicic lava than the adventive cones formed on the flank of the large volcano (Table 1, Fig. $3 b$ ). However, this is not always the case because no basaltic flows were recovered from the small edifice (dive PN13) near the foot of Bounty (Fig. 6b). 


\section{Conclusions}

Based on the interpretation of (Simrad EM12D) seafloor backscatter imagery and multibeam bathymetry studies in the Pitcairn region, it is shown that submarine hotspot activity extends over an area of about $7022 \mathrm{~km}^{2}$. This area includes two large submarine edifices (Bounty and Adams), about five intermediate (500 - $2000 \mathrm{~m}$ high), and about ninety small ( $<500 \mathrm{~m}$ high) edifices. It is calculated that the total volume of erupted lava reached about $5906 \mathrm{~km}^{3}$ (Pitcairn Island included) in a period of about 1.1 Ma. The small edifices occur on the flank and near $(<5 \mathrm{~km})$ the larger edifices as well as up to $35 \mathrm{~km}$ away from the larger ones. They are usually aligned in a preferential $\left(\mathrm{N} 160^{\circ}-180^{\circ}\right.$ and $\left.\mathrm{N} 055^{\circ}\right)$ tectonic (fault, horst-graben and fissure) direction. Evidence for the propagation of magma along a pathway in the oceanic crust is given by the bulging topography of the seafloor along these volcanic alignments. Such rift zones extend from near the summit and the foot of the larger edifices for a radius of more than $20 \mathrm{~km}$.

Volcanic stratigraphy defined on the basis of field observations and lava composition suggest a cyclic eruption. Submersible profiles (5) and surface ship observations (deep towed camera) carried out on the flank of Bounty, between 3000 and $400 \mathrm{~m}$ depth, indicates that there were at least 9 eruptive sequences. These volcanic sequences were arbitrarily classified into those going from the least evolved picritic ( $>7 \%$ olivine), alkali basalt to trachybasalt, trachy-andesites and trachyte. Successive events give rise to more viscous flows consisting of trachybasalt $\left(\mathrm{SiO}_{2}=49-52 \%\right)$, trachy-andesite $\left(\mathrm{SiO}_{2}=53-59 \%\right)$ and trachyte $\left(\mathrm{SiO}_{2}=59\right.$ $63 \%)$. The small edifices $(<500 \mathrm{~m}$ high) differ from the larger edifices since they are essentially composed of silicic lava $\left(\mathrm{SiO}_{2}>52 \%\right)$. A detailed geological profile of one small edifice also shows sequential eruptions (at least 4) of trachy-andesite and trachyte flows. The least evolved alkali

basalt and trachybasalt generally give rise to pillows and giant tubular flows. The most silica (> $55 \%$ ) enriched lava is seen as tabular and blocky flows with large cavities (up to $5 \mathrm{~cm}$ long) and thicker ( $>3 \mathrm{~cm}$ up to $20 \mathrm{~cm}$ ) glassy margins.

The alkali basalt-trachyte suites represent successive crystal fractionated liquids derived from common basanitic and/or picritic basalt melt. The distinct incompatiblemoderately incompatible element ratios $\left[(\mathrm{La} / \mathrm{Sm})_{\mathrm{N}}, \mathrm{Nb} / \mathrm{Y}, \mathrm{Zr} / \mathrm{Y}\right.$ and $\left.\mathrm{K} / \mathrm{Ti}\right]$ between the various basaltic rocks suggests that they were produced from separate parental mantle sources during successive replenishment and mixing in the magmatic reservoirs. The T-MORBs found on the intermediate edifices (Young and Christian) are interpreted as representing ancient flows of pre-hotspot eruptive events on the ancient Farallon plate.

\section{Acknowledgements}

We are particularly indebted to the Captain, the officers and the crew of the N.O. L'ATALANTE and the submersible (NAUTILE) team of GENAVIR for their efficiency and expertise and patience during the Polynaut cruise. We express our gratitude to Capt. $\mathrm{H}$. Andresen and the crew during leg 65 of the F.S. SONNE for their expertise. This cruise was supported by BMFT grant AZ.03R397A5 to P.S. The Polynaut cruise was directed and sponsored by INSU (France) and the Bundes Ministerium Für Bildung und Forschung (BMBF, Germany). One of the authors (Hekinian) received the Alexander von Humboldt Award, which enabled the completion of this research. This work was initiated at IFREMER (Department of Marine Geosciences) by one of the authors (Hekinian) who is particularly indebted to the continued support of the department. We are indebted to M. Bohn, A. Crusson and R. Apprioual for their help with the microprobe analyses, computer data acquisition and 
sample preparation, respectively. We are grateful to Drs. D. Clague, J. Wright, S.D. Weaver and $\mathrm{K}$. Haase for their critical review of the manuscript.

\section{References}

Ackermand D., Hekinian R. and Stoffers, P. 1998. Magmatic sulfides and oxides in volcanic rocks from the Pitcairn hotspot (South Pacific), Mineralogy and Petrology, 64, 149-152.

Bach,W., Hegner, E Erzinger, E. and Stir, M. 1994. Chemical and isotopic variations along the superfast spreading East Pacific Rise from $6^{\circ}$ to $30^{\circ} \mathrm{S}$, Contr. Petrol., 116, 365-380.

Batiza, R. 1996. Magmatic segmentation of mid-ocean ridges: a review, in: MacLeod, C.J. Tyler, P.A. \& Walker, C. L. (Eds.) 1996, Tectonic magmatic and hydrothermal Biological Segmentation of Mid-Ocean Ridges, Geol. Soc. Spec. publ., 118, 103-130.

Batiza R, 1989, Petrology and geochemistry of eastern pacific spreading centers. In: Winterer E.L., Hussong, D.M. \& Decker, R. W. (eds) The eastern pacific Ocean and Hawaii: The Geology of North America, N. Gelogical Society of America, Boulder Colorado, 145-160.

Binard, N., Hekinian, R., and Stoffers, P. 1992. Morphostructural Study and Type of Volcanism over the Pitcairn Hot Spot (South Pacific). Tectonophysics, V.206, pp 245264

Bower S.M. and Woods, A.W., 1997. Control on magma volatile content and chamber depth on the mass erupted during explosive volcanic eruptions, Jour. Geophys. Res. 102, 10,27310,290 .

Clague, D.,A., Reynolds, J.R. and Davis, A.S. 2000. Near Ridge seamount chains in the northeastern Pacific Ocean, J. Geophys. Res. 105, 16,541-16,561.

Chadwick, W.W.Jr., Embley, R.W. and Fox, C.G. 1995. SeaBeam depth changes associated with recent flows, CoAxial segment, Juan de Fuca Ridge: evidence for multiple eruptions between 1981-1993. Geophysical Research Letters, 22, 167-170

Cheminée, J.L., Hekinian, R, Talandier, J. Albarède., F., Devey, C.W., Francheteau, J., and Lancelot, Y. , 1989. Geology of active hot spot: Teahitia-Mehetia region in the south central pacific, Mar. Geophys. Res., 11, 27-50.

Carter, R.M. 1967. The geology of Pitcairn Island, South Pacific, B.P. Bishop Museum, Bull., 231, 1-38.

Cayol, V., Dietrich J.H., Okamura, A.T., and Mikilus, A., 2000. High magma storage rates before the 1983 eruption of Kilauea, Hawaii, Science, 288, 2343-2346.

Davidson J. and de Silva, S, 2000. Composite volcanoes, in Encyclopedia of volcanoes, ed. Sigurdsson, H., Academic Press, London, 663-681.

Devey C.W, K.S. Lackschewitz, D.F. Mertz, B. Bourdon, J.-L. Cheminée, J. Dubois, C. Guivel, R. Hekinian, P. Stoffers, 2002. The initiation and growth of Polynesian hotspot volcanoes, Geology, (submitted).

Duncan R.A. I. McDougall, R.M. Carter and D.S. Coombs, 1974. Pitcairn Island - another Pitcairn hot spot? Nature, 251, 679-682.

Dziak , R.P. Fox, ., C. G., and Schneideret, A. E. 1995. The June-July 1993 seismo-acoustic event at CoAxial segment, Juan de Fuca ridge: evidence for a lateral dike injection, Geophys. Res. Let., 22, 135-138.

Embley R., and Chadwick W.W. Jr. 1994. Volcanic and hydrothermal processes associated with recent phase of seafloor spreading at the northern Cleft segment: Juan de Fuca ridgeJour. Geophys. Res. 99, 4741-4760.

Fisher, R.V. 1966. Mechanism of deposition from pyroclastic flows, Amer. J. Sci., 264, 350363.

Garbe-Shönberg, C-D. 1993. Simultaneous determination of thirty-seven trace elements in twenty -eight international rock standards by ICMS, Geostandards Newsleter, 17, 81-97. 
Gibson, I.L. and Walker G.P.L. 1963. Some composite rhyolite/basalt lavas and related composite dykes in eastern Iceland. Proc. Geol. Ass., 74, 301-318

Govindaraju, K. 1989, Compilation of working values and sample description for 272 geostandards, Geostandards Newsleter, special issue, 13, 1-113.

Guillou, H., Garcia, M.O., and Turpin, L, 1997. Unspiked K-Ar dating of young volcanic rocks from Loihi and Pitcairn hot spot seamounts, J. Volc. Geotherm. Res., 78, 239-249.

Harrison, C. G. A., 1968. Formation of magnetic anomaly patterns by dyke injection, Jour. Geophys. Res., 73, 2137-2142.

Hekinian, R., D. Bideau, P. Stoffers, J.L. Cheminée, R. Muhe, N. Binard, 1991, Submarine Intraplate Volcanism in the South Pacific: Geological Setting and Petrology. Jour. Geophys. Res. V 96, pp. 2109-2138.

Hekinian, R., P. Stoffers, D. Ackermand, S. Révillon, M. Maia, M. Bohn, 1999, Ridgehotspot interaction: the Pacific-Antarctic Ridge and the Foundation seamounts, Mar. Geol., 160, 199-223.

Hekinian, R., Pineau, F., S.Shilobreeva, D.Bideau, E. Gracia, and M. Javoy, 2000, Deep Sea Explosive Activity on the Mid-Atlantic Ridge near 3450'N: Magma Composition, Vesicularity and Volatile Content, J. Volc. Geotherm. Res. 98, 49-77

Johnson, R.H., 1984, Exploration of three submarine volcanoes in the South Pacific, Nat. Geogr. Soc. Res,. Report, 16, 405-419.

Le Bas M.J. and Streckeisen K. 1986, The IUGS systematics of igneous rocks. J. Geol. Soc. Lond. 148, 825-833.

Lister J.R. and R.C. Kerr, 1991, Fluid-mechanical model of cracks propagation and their applications to magma transport in dykes. J. Geophys. Res., 96, 10,049-10,077.

Lonsdale, P.F., 1988. Geography and history of the Louisville Hotspot Chain in the south west Pacific, J. Geophys. Res., 93, 3078-3104.

Michael P. J., Chase, R.L., Allan, J.F., 1989, Petrological and geological variations along the southern Explorer Ridge, northeast Pacific ocean, J. Geol. Res., 94, 13,895-13,918.

Middlemost, E. A. K. 1980, A contribution to the nomenclature and classification of volcanic rocks, Geol. Mag., 117, 51-57.

Niu, Y., D.G., Waggoner, J. Sinton and J.J Mahoney, 1996, Mantle source heterogeneity and melting processes beneath sefloor spreading centers: The East pacific Rise, $18^{\circ}-19^{\circ} \mathrm{S}, \mathrm{J}$. Geophys. Res. 101, 27,511-27,733.

Naar, D. F., and R. N. Hey, 1991 Tectonic evolution of the Easter Microplate, J. Geophys. Res, 96, 7961 - 7993.

Parsons, B. and Sclater, J.G. 1977, An analyses of ocean floor bathymetry and heat flow with age, J. Geophys. Res. 82, 803-827.

Rubin and Pollard, 1987, Origin of blade-like dikes in volcanic rift zone. In; Decker, R.D., Wright, T.L. and Stauffer, P.H. (eds.) Volcanism in Hawaii. US geological Survey Professional Papers, 1350, 1449-1470.

Seyfried, R. and A. Freundt, 2000, Experiments on conduit and eruption behavior of basaltic volcanic eruption, J. Geophys. Res., 105, 23,727-23,740.

Smith, M.M.C. Perfit, M. R. \& Johnasson, I.R. 1994, Petrology and geochemistry of basalts from the southern Juan de Fuca ridge: controls on the spatial and temporal evolution of mid-ocean ridge basalt. Jour. Geophys. Res., 99, 4787-4812.

Smith, W.H.F., and D.T. Sandwell, 1997, Global sea floor topography from satellite altimetry and ship depth soundings, Science, 277, 1956-1962.

Sigurdsson, H. 1987, Dyke injection in Iceland: a review. In: Halls H. C. \& Fahrig W.F. (Eds.) Mafic dyke swarms. Geological society of Canada special papers, 34, 55-64.

Sinton, J.M., S.M. Smaglik, and J.J. Mahoney, 1991, Magmatic processes at supefast midocenic ridges: Glass composition variation alon the East pacific Rise $13^{\circ}-23^{\circ} \mathrm{S}, \mathrm{J}$.

Geophys. Res.,96, 6133-6155 
Stoffers, P., R. Hekinian, D. Ackermand, N. Binard, R. Botz, C.W. Devey, D. Hansen, R. Hodkinson, G. Jeschke, J. Lange, E. Van De Perre, J. Scholten, M. Schmitt, P. Sedwick, J.D.Woodhead, 1990, Active Pitcairn Hotspot found, Mar. Geol, V 95, pp 51-55.

Turcotte, 1982, Magma migration, Ann. Rev. Earth, Planet; Sci., 10, 397-408.

Wilson L., R. S. J. Sparks, and G. P. L. Walker, 1980, explosive eruptions, IV, The control of magma properties and conduit geometry on eruption column behaviour, Geophys. J. R. Astrn. Soc., 63, 117-148.

Woodhead J. and McCulloch M.T., 1989, Ancient seafloor signal in Pitcairn Island and evidence for large amplitude, small length-scale mantle heterogeneity, Earth, planet. Sci. Let., 94, 257-273.

Woodhead J. D., P. Greenwood, R. S. Harmon and P. Stoffers, 1993, Oxygen isotope evidence for recycled crust in the source of EM-type ocean island basalts, nature, 362, 809-813.

Woodhead J. D. and C. Devey, 1993, Geochemistry of the Pitcairn seamounts, I: source character and temporal trends, Earth, Planet. Lett. 116, 81-99.

Yoder H.S. 1973, Contemporaneous Basaltic and Rhyolitic Magma, Am.

Mineralogist, 58, 153-173 


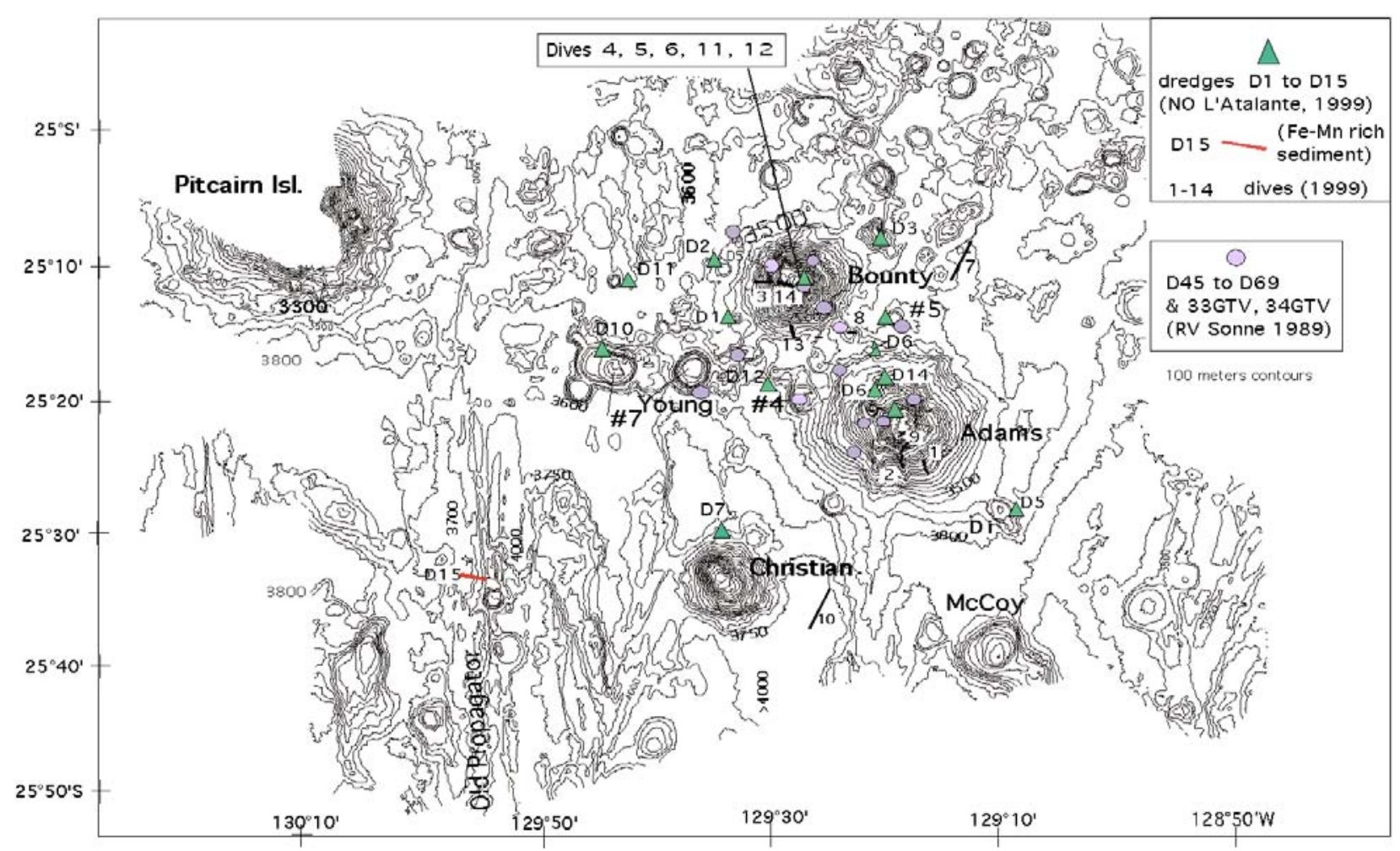

Fig. 1. (a) Satellite altimetry from Smith and Sandwell, (1997) showing hotspots and volcanic chains of the South Pacific Region. $\mathrm{M}=$ Macdonald seamount, E.M. = Easter Microplate and J.F.M. = Juan Fernandez Microplate. (b) Bathymetric chart (100 m contour lines) obtained from multibeam Simrad EM12D system with the N.O. L'ATALANTE during the 1999 Polynaut cruise of the Pitcairn region in the South Pacific. Two sets of sample distributions are shown: 1) the triangle and heavy-lines indicates dredge hauls (D.) and the submersible (NAUTILE) tracks respectively presented in this study, and 2) the circles show the distribution of other dredged (1989 FS. SONNE cruise) samples studied previously (Stoffers et al., 1989; Binard et al., 1992; Ackermand et al., 1998). The larger volcanic edifices are named and others are numbered (\#4, \#5 \& \#7, Binard et al., 1992). 

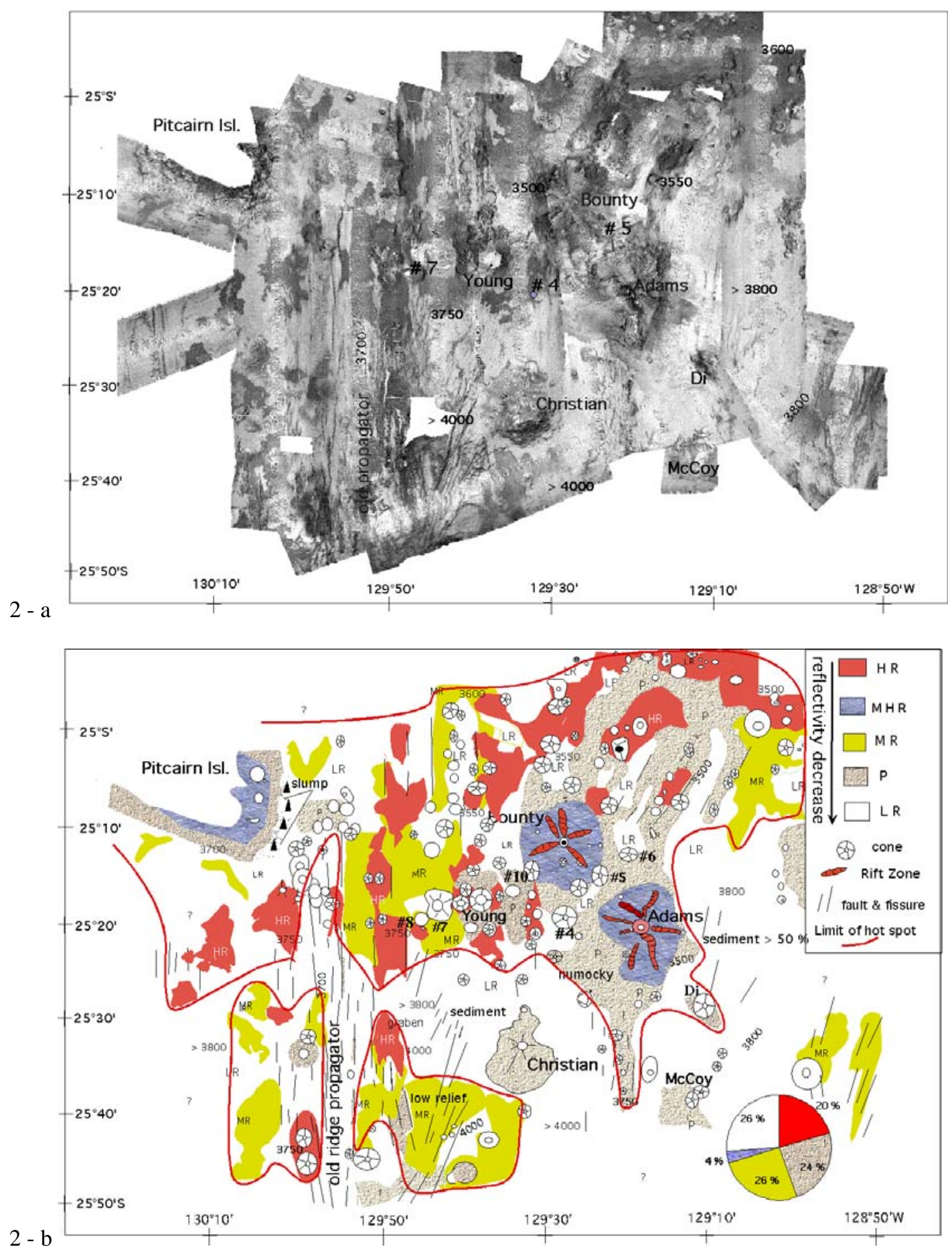

Fig. 2. (a) Seafloor backscatter imagery obtained from the multibeam Simrad EMD12 system, (N.O. L'ATALANTE) during the Polynaut cruise in the Pitcairn region. (b) The morpho-structural interpretation of the various volcanic constructions is based on the reflectivity of the seafloor, which is a function of the backscattered signal from the sonar system. The hotspot activity includes the high (HR), middle-high (MHR), middle (MR) and patchy (hummocky, P) type of seafloor reflectivity. The inferred boundary of the hotspot is indicated by a heavy dashed-line. Most silicic lava is found on small volcanic cones showing preferential alignment away from the larger edifices (i.e. Bounty and Adams) (see text). 

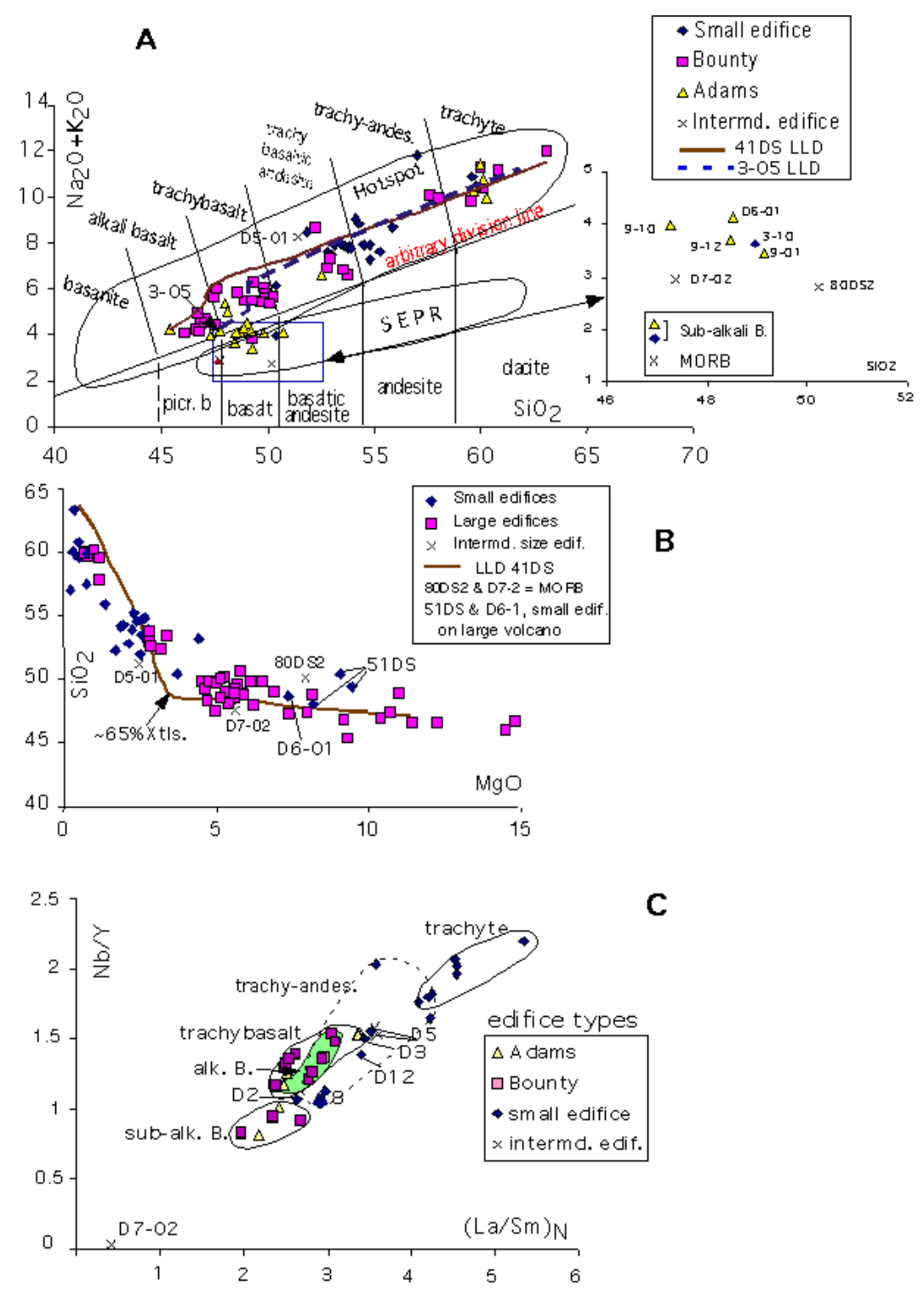

Fig. 3. (a) $\mathrm{SiO}_{2}$ and $\mathrm{Na}_{2} \mathrm{O}+\mathrm{K}_{2} \mathrm{O}$ variation diagram for the classification of various types of volcanics modified after Middlemost, (1980) and Le Bas and Streckeisen, (1986). The field of the trachybasalt is extended into that of the conventional trachybasaltic andesite. The enclosed fields of other submarine hotspot volcanoes shown are from data published by Cheminey et al., 1988, Stoffers et al., (1989), Binard et al., (1992), Woodhead and Devey, (1993) and Ackermand et al., (1998). The field of the South East Pacific Rise (SEPR) volcanics shown is from Sinton et al., (1991), Bach et al., (1994), Niu et al., (1996) and Hekinian et al., (1999). A continuous dark line separates the two fields between MORB, south EPR and hotspot volcanics. The aphyric and glassy rocks from the Pitcairn hotspot are plotted (Table 3 and 4). The small box (MORB) represents the field of East Pacific N-, T- and E-MORBs (data compiled by Hekinian). The enlarged inset of this box includes the sub-alkali basalts (9-01, -10, -12, D6-01) and TMORBs (D7 and 80DS) from the Pitcairn hotspot. The liquid line of descent (LLD) defining a crystal-liquid fractionation trend was calculated from a basanite (solid line, 41DS, Hekinian et al., 1991) and picritic basalt (dashline, 3-05, table 3). The various types of volcanics are regrouped into their corresponding edifice sizes (e.g. Bounty \& Adams = large edifices). (b) $\mathrm{MgO}-\mathrm{SiO}_{2}$ variation diagram of the various types of edifices showing a crystal fractionation trend (LLD). About 65\% crystallization (Xlts.) occurs before the melt becomes enriched in silica. Samples D6-1 and dredge 51DS (Binard et al., 1992) are from small adventive cones from Adams and Bounty respectively. (c) Bulk rock $\mathrm{Nb} / \mathrm{Y}-(\mathrm{La} / \mathrm{Sm})_{\mathrm{N}}$ variation diagrams with respect to the rock types and to the size of volcanic edifices (Bounty \& Adams = large edifices). 

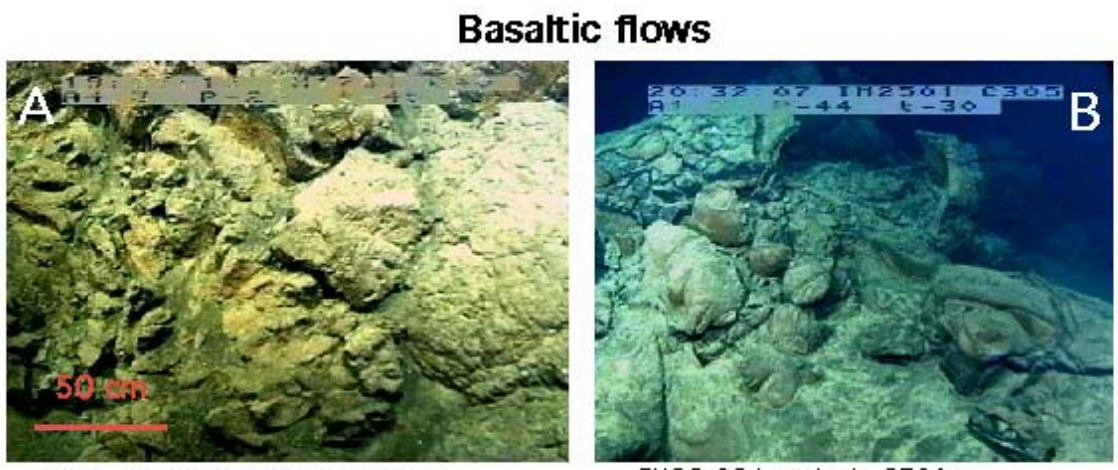

PN14-03, pillow (alk.B.), $1761 \mathrm{~m}$.

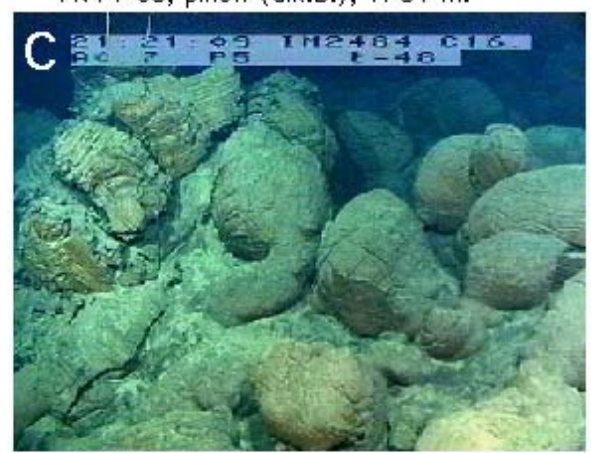

PN03-03 haystack, $2501 \mathrm{~m}$.

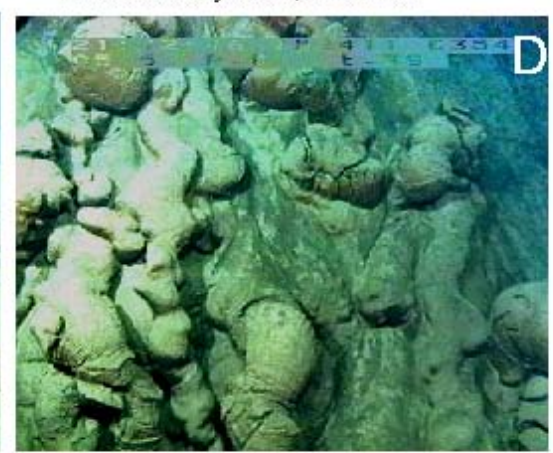

PNO3-04, picritic basalt, $2404 \mathrm{~m}$.

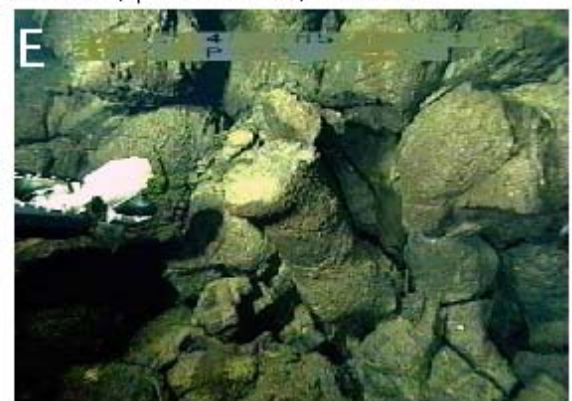

PNO3-05, alkali basalt, $2411 \mathrm{~m}$.

PNO5-08, small pillows mound, $531 \mathrm{~m}$
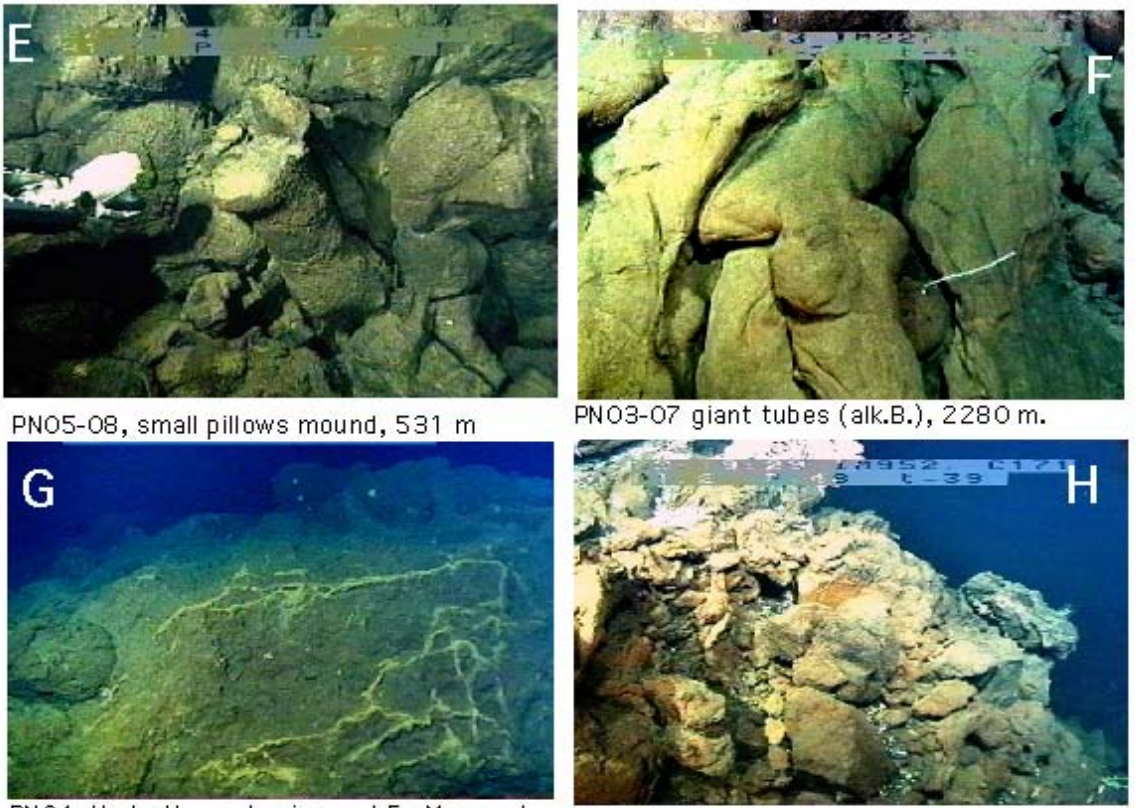

PN03-07 giant tubes (alk.B.), $2280 \mathrm{~m}$.

PNO4, Hydrothermal veins and $\mathrm{Fe}-\mathrm{Mn}$ crust at $426 \mathrm{~m}$ depth.

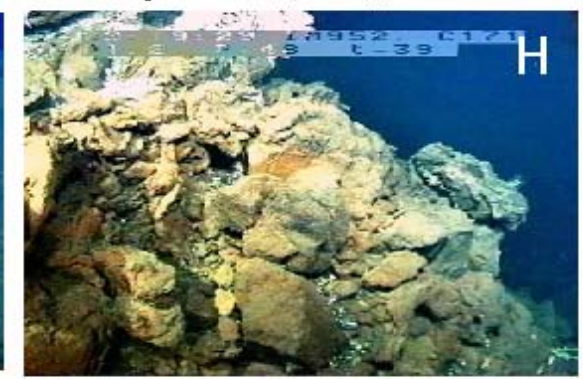

PN14-13, trachybasalt and volcanic debris, $952 \mathrm{~m}$.

Fig. 4. Bottom photograph of volcanic flows showing different morphologies encountered on the Bounty volcano in the Pitcairn region. (a) Pillow lava of alkali basalt (PN14-03) with radial jointing and interstitial debris of hydrothermal and sand sized volcanics. (b) Haystack of collapsed bulbous flow and glassy slabs. (c) Pillow lava of picritic basalt (PN3-04) with "elephant trunks" and striated glassy flow surface. (d) Pillow lava of picritic basalt (PN3-05) from the flank of the Bounty. (e) Scarp (flow front) of small size ( $<40 \mathrm{~cm}$ in length) alkali basalt pillow lava near the top of Bounty. (f) Giant lava tubes of picritic basalt (PN3-07) with "cork screw" smooth surface flowing down slope. (g) Hydrothermal veins due to fluid discharge at the top of a mound made up of Feoxyhydroxide crust covering bulbous pillow, (Bounty volcano). (h) Pillow lava mound and tubular flows associated with volcanic debris with ash flow close to a trachybasalt PN14-13. 

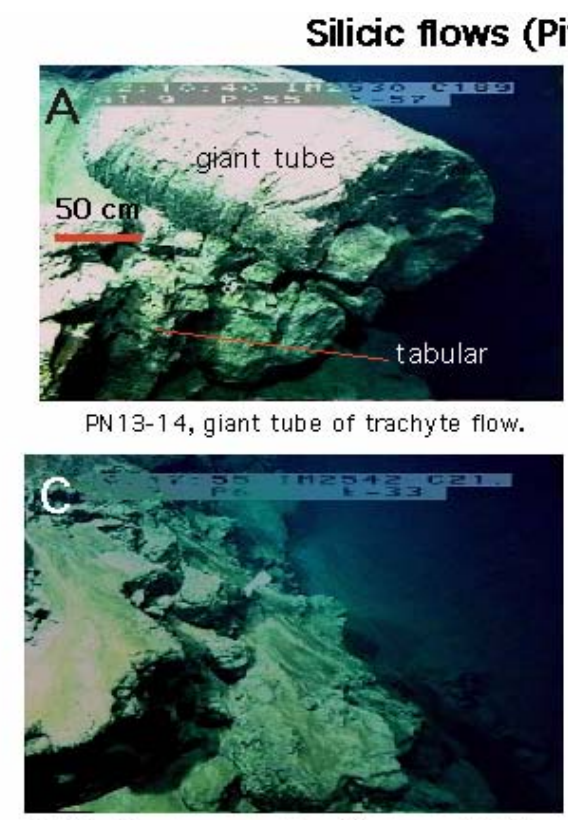

PN13, Spiny layered slab with brown $2542 \mathrm{~m}$.

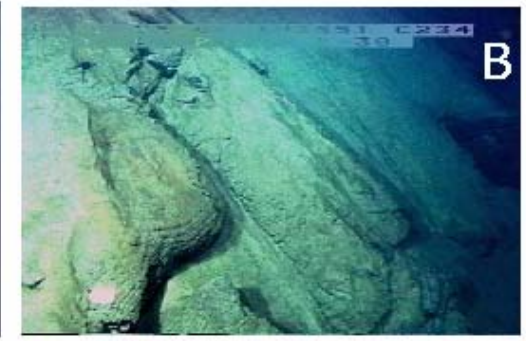

P15, Giant tubes (trachyte), $2551 \mathrm{~m}$.
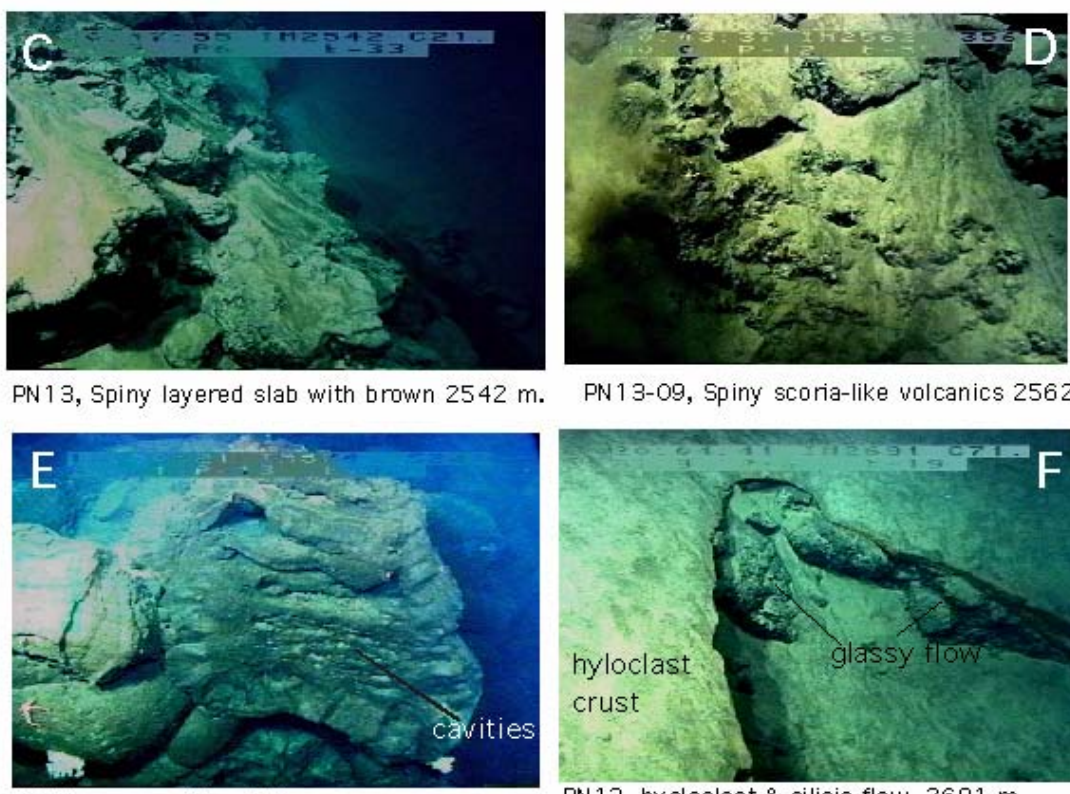

PN13-09, Spiny scoria-like volcanics $2562 \mathrm{r}$

PN04, gas cavities, $571 \mathrm{~m}$.

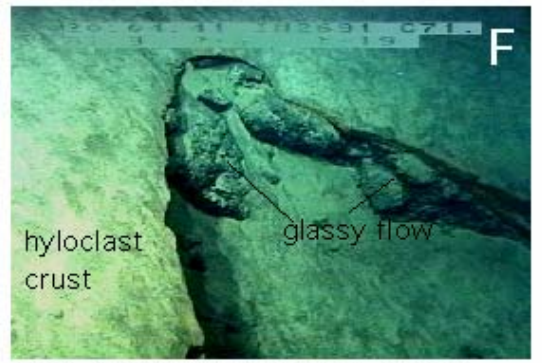

PN 13, hy aloclast \& silicic flow, $2691 \mathrm{~m}$.

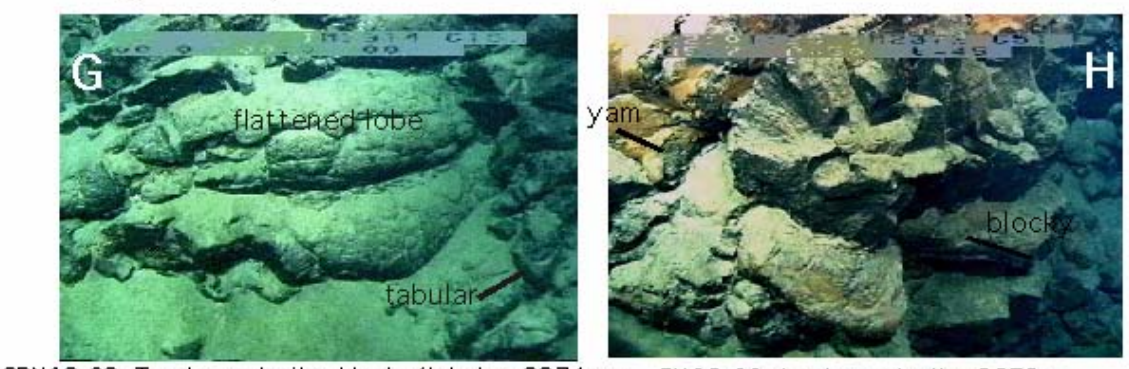

SPN 13-02, Trachy-ande site, blocky/tabular, $2974 \mathrm{~m}$. PN03-06, trachy-andesite, $2372 \mathrm{~m}$.

Fig. 5. Bottom photograph of various types of volcanic flows encountered on a small (dive PN13) adventive cone and on the Bounty (PN3) volcano in the Pitcairn hotspot. (a) Giant half broken tube on top of tabular and blocky trachytic (PN13-14) lava outcropping along a near vertical slope at $2530 \mathrm{~m}$ near the summit of a small volcanic edifice. (b) Giant tubular flow of trachyte (PN13-15) oriented down slope and partially covered by hydrothermal material mixed with pyroclastic debris and pelagic sediment at $2551 \mathrm{~m}$. (c) Blocky and tabular trachytic lava with "spiny" glassy surface and light-brown hydrothermal sediment. (d) "Spiny" tabular flows (PN13-09) are partially coated with brown colored hydrothermal sediment. (e) Blocky-tabular trachytic flow (dive PN04) shows large gas cavities. Picture taken at the top of the Bounty volcano (574 m) near sample site PN4-03. (f) Crust of hyaloclastite (ash + shards + hydrothermal sediment) lying on top of glassy silicic flows at $2691 \mathrm{~m}$. (g) Flattened lobes of tubular and tabular flows (trachy-andesite, PN13-02) taken at $2974 \mathrm{~m}$ located on the flank, near the base of a small volcano. (h) Trachy-andesite blocks overlaid by pillow with radial jointing, at $2372 \mathrm{~m}$ on the flank of the Bounty volcano at sample site PN3-06. 


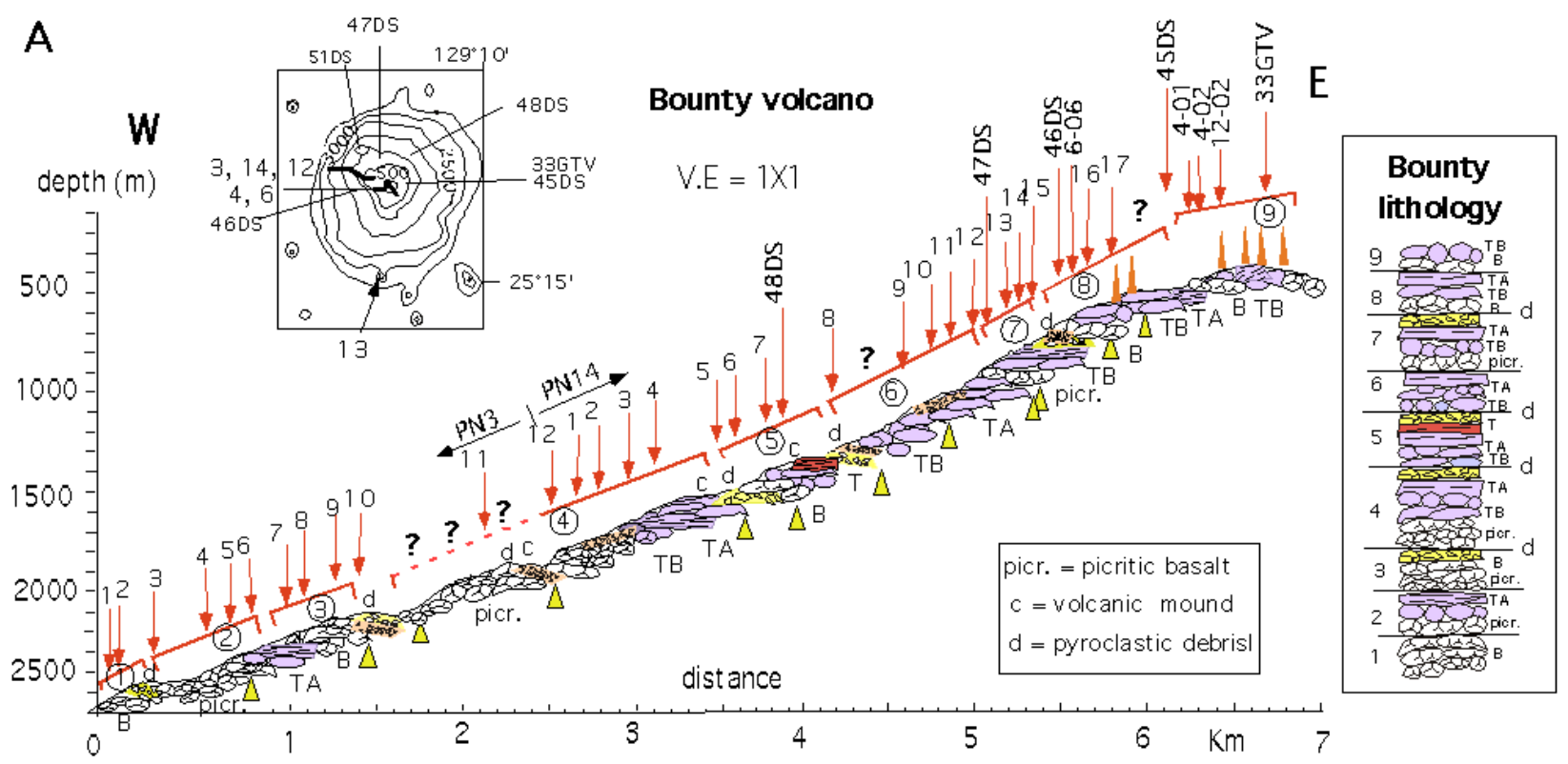

B

\section{Lithological variation of volcanics from Pitcairn Hotspot}

\begin{tabular}{|c|c|}
\hline types & Morphlogy \\
\hline $\begin{array}{c}\text { piicritic basalt } \\
\text { alkali-basalt } \\
\text { B }\end{array}$ & ${ }_{\text {pillows }}$ \\
\hline $\begin{array}{c}\text { trachybasalt } \\
\text { TB } \\
\text { trachy-andesite } \\
\text { TA }\end{array}$ & $\begin{array}{l}800 \text { pillows } \\
\Leftrightarrow \text { giant tubes } \\
\Rightarrow \text { blocky \& tabular }\end{array}$ \\
\hline $\begin{array}{c}\text { Trachyte } \\
T\end{array}$ & $\begin{array}{c}\Rightarrow]_{\text {giant tubes }}^{\text {flat-lobes \& }} \\
\text { \& blocky, tabular } \\
\text { \& spiny flow }\end{array}$ \\
\hline $\begin{array}{l}\text { Pyroclasts } \\
\text { d } \\
\text { Hyaloclastite }\end{array}$ & 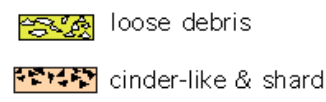 \\
\hline & $\begin{array}{l}\Delta \Delta \quad \text { talus } \\
(1) \text { volcanic unit }\end{array}$ \\
\hline
\end{tabular}

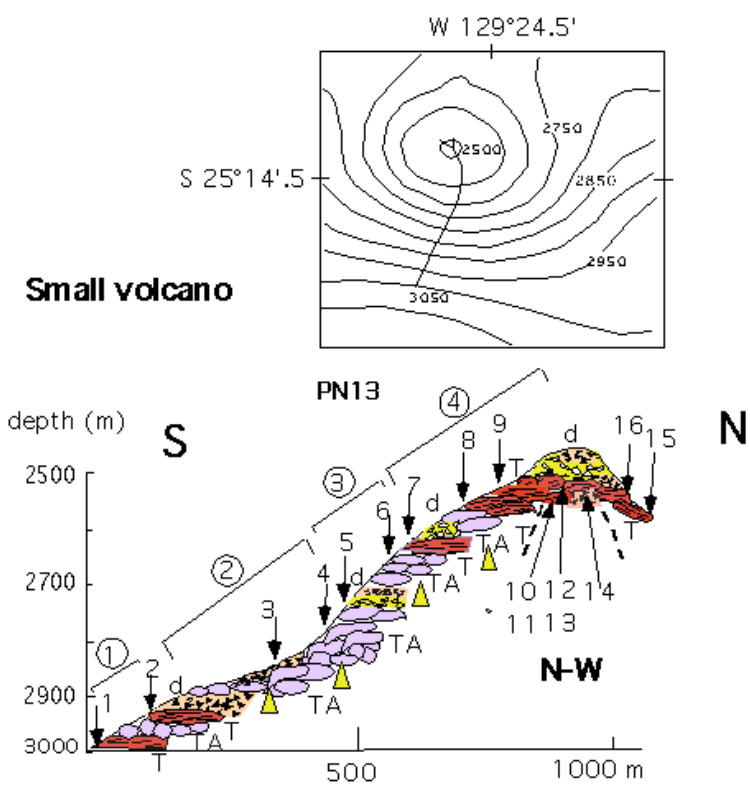

Fig. 6. (a) Composite profile of dives PN03, $-06,-12$, and -14 shows the geology of the various flows along the slope of Bountry volcano in the Pitcairn hotspot. The inset shows the simplified bathymetric map of the Bounty volcano and adventive cones with the submersible dives. The arrows correspond to the sampling sites: dives PN3 and PN14 have one set of numbers, the others have two sets (e.g. 6-06) of numbers. Other sample sites (DS and GTV) from previous cruises of the FS SONNE (leg 65, 1989) (Stoffers et al., 1989; Binard et al., 1992) are also projected along the same profile. Trachyte and trachy-andesite were collected from dredge station 48DS. The geology of the area along the profile near stations 3-11, at $2200 \mathrm{~m}$ depth (unit 4 marked by dashed-line) was inferred from field observation. (?) Indicates uncertainties due to lack of sampling. A sketched stratigraphic column with the various volcanic sequences is shown on the right hand side of the profile. A summary of the parameters used for constructing this diagram is shown in Table 5. The key of the legend is shown on Figure 6b. (b) Geology of dive profile PN13 along the slope of a small conical seamount (about $500 \mathrm{~m}$ high) located on the south slope of the Bounty volcano (Figures 1b and 6a). Lava morphology and rock types are shown on the left-hand side of the diagram. The sample sites are indicated by a number (1). Sample 7 (PN13-07) was not analyzed and its composition was inferred from its petrography and morphology. 
Table 1 Sample descriptions from the Pitcairn hotspot in the South Pacific near $25^{\circ} \mathrm{S}-130^{\circ} \mathrm{W}$.

\begin{tabular}{lcl} 
Sample \# & Depth $(\mathrm{M})$ & \multicolumn{1}{c}{ Description } \\
\hline PN1-01 & 1474 & trachyte, highly vesicular, blocky / tabular, Adams \\
\hline PN2-01 & 1428 & alkali basalt, tubular flow with elongated vesicles, Adams \\
PN2-05 & 1010 & alkali basalt, talus breccia, vesicles \\
\hline PN3-01 & 2566 & alk. basalt,pillow, in situ, Bounty \\
PN3-02 & 2568 & alk. basalt,pillow tube, in situ, ash, Bounty \\
PN3-03 & 2500 & alk. basalt,pillow, hay-stack \\
PN3-04 & 2480 & picritic basalt, giant tube in situ \\
PN3-05 & 2408 & picritic basalt, sulfide-globule, in situ \\
PN3-06 & 2376 & trachy-andesite, pillow, sulfide-globules, in situ, \\
PN3-07 & 2276 & alk. basalt, giant tube, in situ \\
PN3-08 & 2250 & alk. basalt,pillow \& volcanoclast \\
PN3-09 & 2194 & picritic basalt, pillow, in situ \\
PN3-10 & 2165 & picritic basalt, pillow \& slab (hyaloclast) pyroclast, in situ \\
PN3-11 & 1957 & picritic basalt, pillow in situ \& pyroclast \\
PN3-12* & 1908 & pillow tube, in situ \\
\hline PN4-01 & 668 & trachybasalt, blocky, talus, Bounty \\
PN4-02 & 614 & trachybasalt, massive flow \\
PN4-03 & 573 & blocky and bulbous glassy and vesicular flows \\
PN4-05 & 421 & trachybasalt, pillow \\
\hline PN5-01 & 840 & trachybasalt, pillow \& Fe-Si oxyhydroxide, Bounty \\
PN5-02 & 783 & trachybasalt, giant tube \\
PN5-08* & 531 & pillow lava mound, vesicular, top of Bounty \\
\hline PN6-06 & 712 & alkali basalt, pillow \& hyaloclast, Bounty \\
\hline PN7-01 & 3500 & trachy-andesite, tabular/blocky, foot of small edifice \\
\hline PN8-01 & 3131 & trachybasalt, pillow, sulfide globules, small edifice \\
PN8-03 & 2951 & trachy-andesite, tabular \& blocky \\
PN8-08 & 2585 & trachy-andesite, tabular \\
\hline PN9-01 & 778 & sub-alkali basalt, spiny flow, hyloclast, hydrothermal sediment \\
PN9-10 & 400 & sub-alkali basalt, vesicular pillow, near top of Adams \\
PN9-12 & 212 & sub-alkali basalt, tubular \& vesicular, corals, top of Adams \\
\hline PN11-03 & 605 & trachybasalt, vesicular pillow ,Bounty \\
\hline & &
\end{tabular}




\begin{tabular}{|c|c|c|}
\hline PN12-01 & 607 & trachybasalt, vesicular pillow, Bounty \\
\hline PN12-02 & 514 & trachybasalt, vesicular, Bounty \\
\hline PN12-07 & 428 & Fe-oxyhydroxide, pillow, Bounty \\
\hline PN13-01 & 3000 & trachyte, blocky-tabular, small edifice on Bounty \\
\hline PN13-02 & 2914 & Trachyte, blocky-tabular \\
\hline PN13-03 & 2896 & trachy-andesite, giant tube, \& hydrothermal sediment \\
\hline PN13-04 & 2896 & trachy-andesite \\
\hline PN13-05 & 2745 & Hyaloclast \& sediment slab \\
\hline PN13-06* & 2699 & Spiny flow \& hyloclast, hydrothermal sediment \\
\hline PN13-07 & 2650 & trachyte, blocky-tabular with elongated vesicles \\
\hline PN13-08 & 2627 & trachy-andesite, "spiny", top of flat flow \\
\hline PN13-09 & 2562 & trachyte in situ \\
\hline PN13-10 & 2553 & trachyte, contact zone, blocky-tabular \& pillows \\
\hline PN13-11 & 2546 & trachyte, giant tube with scoria-like surface \\
\hline PN13-12 & 2546 & trachyte,blocky-tabular \\
\hline PN13-13 & 2543 & trachyte,blocky-tabular \\
\hline PN13-14 & 2532 & trachyte, giant flatened tubular flow \\
\hline PN13-15 & 2566 & giant tube with thick glassy coats \\
\hline PN13-16 & 2546 & trachyte, highly vesicular (scoria-like) \\
\hline PN14-01* & 1890 & pillow lava in situ, Bounty \\
\hline PN14-02 & 1864 & ash \& sediment \\
\hline PN14-03 & 1762 & trachybasalt, pillow, pyroclast \& ash \\
\hline PN14-04 & 1705 & trachy-andesite, blocky slab in situ \& ash \\
\hline PN14-05 & 1613 & hyaloclastite \& sediment \\
\hline PN14-06 & 1614 & trachybasalt, pillow, pyroclast, \& ash \\
\hline PN14-07* & 1506 & pillow, associated with giant tube \\
\hline PN14-08 & 1404 & trachybasalt, pillow, scarp, talus, hyaloclast, crust \& ash \\
\hline PN14-09 & 1284 & trachybasalt, pillow \\
\hline PN14-10 & 1154 & trachy-basalt, giant tube \\
\hline PN14-11 & 1138 & trachy-andesite, \& black ash \\
\hline PN14-12 & 1032 & trachy-andesite, giant tube \\
\hline PN14-13 & 950 & trachybasalt, pillow mound, ash \\
\hline PN14-14 & 866 & trachybasalt, pillow \& ash \\
\hline PN14-15 & 816 & trachybasalt, giant tube, ash \& pyroclast \\
\hline
\end{tabular}




\begin{tabular}{|c|c|c|}
\hline $\begin{array}{l}\text { PN14-16* } \\
\text { PN14-17 }\end{array}$ & $\begin{array}{l}723 \\
694 \\
\end{array}$ & $\begin{array}{l}\text { giant lava tube, flow front, rift zone } \\
\text { hydrothermal chimney }\end{array}$ \\
\hline PNDR1-01 & 3100 & Trachyte, gray, large vesicles, small edifice \\
\hline PNDR2-01 & 3400 & trachybasalt, pillow \& MnOx coat, small edifice \\
\hline PNDR3-01 & 3000 & trachybasalt, vesicular, small edifice \\
\hline PNDR5-01 & 3400 & trachybasalt, vesicular, popping rock, intermediate size edifice \\
\hline PNDR6-01 & 2900 & alk. basalt, fresh \& vesicular, small edifice on Adams \\
\hline PNDR7-02 & 2800 & T-MORB, pillow aphyric, MnOx coat, small edifice on Christian \\
\hline PNDR10-04* & 3450 & Basaltic rock, altered \& MnOx coat, \# 7 intermediate size edifice \\
\hline PNDR11-01 & 3400 & trachy-andesite, highly vesicular, small edifice \\
\hline PNDR11-07 & 3450 & trachy-andesite, highly vesicular, small edifice \\
\hline PNDR12-01 & 3000 & trachy-andesite, vesicular, small edifice \\
\hline PNDR13-03 & 2700 & trachy-andesite, highly vesicular, small edifice \\
\hline PNDR14-01 & 1900 & alk. basalt, vesicular, Adams \\
\hline
\end{tabular}

$\mathrm{PN}=$ Polynaute NAUTILE, dives \# and sample \#.

PNDR = dredge, the dredges depths are averaged.

$\left(^{\star}\right)$ no analyses,

Small edifices are equal or less than $500 \mathrm{~m}$ high and Large edifices $>2000 \mathrm{~m}$ high

Bounty and Adams are large edifices. 
Table 2 Estimation of hotspot volcanism from sea floor morphology and structure

Volcanic edifices less than $3500 \mathrm{~m}$ depth.

\begin{tabular}{lcc} 
Size & \# of edifices & $\mathrm{km}^{3}$ \\
\hline large edifice & 2 & 1168 \\
intermd. edif. & 5 & 159 \\
small edifice & 90 & 47 \\
Pitcairn Island & 1 & 1511 \\
total edif. & 99 & 2885
\end{tabular}

Sea floor between 3500 and 3800 m depth.

\begin{tabular}{lcc}
\hline Morphology & $\mathrm{km}^{2}$ & $\mathrm{~km}^{3^{*}}$ \\
\hline HR & 1946 & 584 \\
patchy & 2266 & 680 \\
MLR & 2462 & 739 \\
MHR & 349 & 105 \\
Pitcairn Isl. & 3050 & 915 \\
total sea floor & 7022 & 3022
\end{tabular}

* The volume of hot spot volcanism was calculated from bathymetry and

from the interpretation of seafloor backscatter imagery images (Fig. 1b, $2 a$ and 2b).

It was assumed a crustal thickness of $300 \mathrm{~m}$ for the sea floor at $3500-3800 \mathrm{~m}$ depth

Large edifices $>2000 \mathrm{~m}$ high, small edifices $\leq 500 \mathrm{~m}$ high.

edif. = edifice 
Table 3 Bulk rock analyses of volcanic rocks collected by submersible from the Pitcairn hotspot.

\begin{tabular}{|c|c|c|c|c|c|c|c|c|c|c|c|c|c|c|c|c|c|c|c|c|c|c|c|}
\hline $\begin{array}{l}\text { Type } \\
\text { sample } \\
\text { Depth (m) }\end{array}$ & $\begin{array}{c}T \\
1-01 \\
2474\end{array}$ & $\begin{array}{c}T \\
1-01 d \\
2474\end{array}$ & $\begin{array}{r}\text { alk.B. } \\
2-01 \\
1595\end{array}$ & $\begin{array}{r}\text { alk.B. } \\
2-05 \\
1010\end{array}$ & $\begin{array}{c}\text { Picr.B. } \\
3-04 \\
2480\end{array}$ & $\begin{array}{c}\text { Picr.B. } \\
3-05 \\
2408\end{array}$ & $\begin{array}{c}\text { alk.B. } \\
3-8 \\
2250\end{array}$ & $\begin{array}{c}\text { Picr.B. } \\
3-09 \\
2194\end{array}$ & $\begin{array}{c}\text { Picr.B. } \\
3-10 \\
2165\end{array}$ & $\begin{array}{c}\text { Picr.B. } \\
3-11 \\
1957\end{array}$ & $\begin{array}{l}\text { TB } \\
4-01 \\
668\end{array}$ & $\begin{array}{l}\text { TB } \\
4-02 \\
614\end{array}$ & $\begin{array}{l}\text { TB } \\
4-05 \\
421\end{array}$ & $\begin{array}{l}\text { TB } \\
5-01 \\
840\end{array}$ & $\begin{array}{l}\text { TB } \\
5-02 \\
783\end{array}$ & $\begin{array}{r}\text { TA } \\
7-1 \\
3500\end{array}$ & $\begin{array}{c}\text { TA } \\
8-01 \\
3131\end{array}$ & $\begin{array}{c}\text { TA } \\
8-03 \\
2951\end{array}$ & $\begin{array}{c}\text { TA } \\
8 \text { - 03d. } \\
2951\end{array}$ & $\begin{array}{c}\text { TA } \\
8-08 \\
2585\end{array}$ & $\begin{array}{c}\text { Sub alk.B. } \\
\begin{array}{c}9-01 \\
778\end{array}\end{array}$ & $\begin{array}{c}\text { Sub alk.B. } \\
9-10 \\
400\end{array}$ & $\begin{array}{c}\text { Sub alk.B. } \\
\begin{array}{c}9-12 \\
212\end{array}\end{array}$ \\
\hline $\mathrm{SiO}_{2} \mathrm{Wt} \%$ & 60,09 & n.d. & 48,12 & 47,99 & 46,64 & 46,83 & 47,41 & 47,03 & 48,94 & 47,49 & 49,33 & 48,89 & 49,69 & 49,37 & 49,8 & 53,46 & 52,97 & 53,89 & n.d. & 53,86 & 49,09 & 47,28 & 48,42 \\
\hline $\mathrm{TiO}_{2}$ & 0,54 & n.d. & 3,37 & 3,28 & 2,37 & 2,64 & 3,04 & 2,52 & 2,62 & 2,57 & 3,65 & 3,66 & 3,53 & 3,53 & 3,56 & 1,89 & 1,94 & 1,96 & n.d. & 1,98 & 2,52 & 2,96 & 2,73 \\
\hline $\mathrm{Al}_{2} \mathrm{O}_{3}$ & 17,79 & n.d. & 15,01 & 15,09 & 12,54 & 13,13 & 14,18 & 13,4 & 12,97 & 13,94 & 16 & 15,81 & 16,98 & 15,51 & 15,69 & 15,17 & 15,16 & 15,51 & n.d. & 15,67 & 14,36 & 15,16 & 15,64 \\
\hline $\mathrm{Fe}_{2} \mathrm{O}_{3} \mathrm{~T}$ & 6,91 & n.d. & 10,87 & 11,39 & 12,55 & 11,66 & 11,41 & 11,61 & 11,98 & 11,8 & 11,08 & 11,08 & 9,93 & 10,27 & 10,22 & 10,65 & 10,32 & 10,41 & n.d. & 10,12 & 11,2 & 12,77 & 12,02 \\
\hline $\begin{array}{l}\mathrm{Fe}_{2} \mathrm{O}_{3} \\
\mathrm{FeO}\end{array}$ & $\begin{array}{l}\text { n.d. } \\
\text { n.d. }\end{array}$ & $\begin{array}{l}\text { n.d. } \\
\text { n.d. }\end{array}$ & $\begin{array}{l}\text { n.d. } \\
\text { n.d. }\end{array}$ & $\begin{array}{l}\text { n.d. } \\
\text { n.d. }\end{array}$ & $\begin{array}{l}\text { n.d. } \\
\text { n.d. }\end{array}$ & $\begin{array}{l}\text { n.d. } \\
\text { n.d. }\end{array}$ & $\begin{array}{l}\text { n.d. } \\
\text { n.d. }\end{array}$ & $\begin{array}{l}\text { n.d. } \\
\text { n.d. }\end{array}$ & $\begin{array}{l}\text { n.d. } \\
\text { n.d. }\end{array}$ & $\begin{array}{l}\text { n.d. } \\
\text { n.d. }\end{array}$ & $\begin{array}{l}\text { n.d. } \\
\text { n.d. }\end{array}$ & $\begin{array}{l}\text { n.d. } \\
\text { n.d. }\end{array}$ & $\begin{array}{l}\text { n.d. } \\
\text { n.d. }\end{array}$ & $\begin{array}{l}\text { n.d. } \\
\text { n.d. }\end{array}$ & $\begin{array}{l}\text { n.d. } \\
\text { n.d. }\end{array}$ & $\begin{array}{l}\text { n.d. } \\
\text { n.d. }\end{array}$ & $\begin{array}{l}\text { n.d. } \\
\text { n.d. }\end{array}$ & $\begin{array}{l}\text { n.d. } \\
\text { n.d. }\end{array}$ & $\begin{array}{l}\text { n.d. } \\
\text { n.d. }\end{array}$ & $\begin{array}{l}\text { n.d. } \\
\text { n.d. }\end{array}$ & $\begin{array}{l}\text { n.d. } \\
\text { n.d. }\end{array}$ & $\begin{array}{l}\text { n.d. } \\
\text { n.d. }\end{array}$ & $\begin{array}{l}\text { n.d. } \\
\text { n.d. }\end{array}$ \\
\hline $\mathrm{MnO}$ & 0,17 & n.d. & 0,39 & 0,15 & 0,16 & 0,16 & 0,15 & 0,15 & 0,15 & 0,16 & 0,14 & 0,14 & 0,12 & 0,13 & 0,13 & 0,19 & 0,17 & 0,17 & n.d. & 0,16 & 0,15 & 0,21 & 0,14 \\
\hline $\mathrm{MgO}$ & 0,58 & n.d. & 5,41 & 6,25 & 12,25 & 9,19 & 7,96 & 10,37 & 11 & 10,72 & 5,65 & 5,82 & 5 & 4,65 & 4,54 & 2,56 & 2,72 & 2,76 & n.d. & 2,22 & 6,88 & 7,37 & 4,71 \\
\hline $\mathrm{CaO}$ & 2,27 & n.d. & 9,42 & 9,3 & 7,82 & 8,89 & 7,81 & 8,13 & 7,82 & 8,02 & 8,41 & 8,34 & 8,59 & 7,75 & 7,74 & 5,14 & 5,21 & 5,25 & n.d. & 5,3 & 11,37 & 7,54 & 10,42 \\
\hline $\mathrm{Na}_{2} \mathrm{O}$ & 6,57 & n.d. & 3,45 & 3,9 & 3,07 & 3,23 & 4,04 & 3,35 & 2,88 & 3,21 & 3,9 & 3,87 & 3,86 & 4,41 & 4,22 & 4,99 & 4,62 & 4,96 & n.d. & 4,84 & 2,77 & 3,03 & 3,01 \\
\hline $\mathrm{K}_{2} \mathrm{O}$ & 4,27 & n.d. & 1,56 & 1,48 & 1,14 & 1,27 & 1,6 & 1,37 & 0,75 & 1,27 & 1,63 & 1,61 & 1,6 & 1,91 & 1,86 & 2,98 & 2,86 & 2,84 & n.d. & 2,98 & 0,71 & 0,9 & 0,69 \\
\hline $\mathrm{P}_{2} \mathrm{O}_{5}$ & 0,22 & n.d. & 0,68 & 0,66 & 0,44 & 0,46 & 0,61 & 0,49 & 0,37 & 0,48 & 0,79 & 0,8 & 0,76 & 0,88 & 0,9 & 1,08 & 1,16 & 1,2 & n.d. & 1,18 & 0,38 & 0,43 & 0,4 \\
\hline LOI & 0,53 & n.d. & 0,43 & n.d. & 0,37 & 0,91 & 0,63 & 0,79 & 0,1 & 0,84 & 0,03 & 0,01 & 0,19 & 0,42 & 0,34 & 1,06 & 1,72 & 1,48 & n.d. & 2,02 & 0,26 & 3,4 & 1,82 \\
\hline Total & 99,94 & n.d. & 98,71 & 51,5 & 99,35 & 98,37 & 98,84 & 99,21 & 99,58 & 100,5 & 100,61 & 100,03 & 100,25 & 98,83 & 99 & 99,17 & 98,85 & 100,43 & n.d. & 100,33 & 99,69 & 101,05 & 100 \\
\hline $\mathrm{K} / \mathrm{Ti}$ & 10,96 & n.d. & 0,64 & 0,70 & 0,67 & 0,67 & 0,73 & 0,75 & 0,39 & 0,68 & 0,62 & 0,61 & 0,63 & 0,75 & 0,72 & 2,18 & 2,04 & 2,01 & n.d. & 2,09 & 0,39 & 0,42 & 0,35 \\
\hline $\mathrm{Na}_{2} \mathrm{O}+\mathrm{K}_{2} \mathrm{O}$ & 10,84 & n.d. & 5,01 & 5,38 & 4,21 & 4,50 & 5,64 & 4,72 & 3,63 & 4,48 & 5,53 & 5,48 & 5,46 & 6,32 & 6,08 & 7,97 & 7,48 & 7,80 & n.d. & 7,82 & 3,48 & 3,93 & 3,70 \\
\hline La ppm & 78,95 & 75,34 & 36,36 & 34,63 & 27,32 & 29,56 & 41,54 & 29,88 & 19,80 & 31,86 & 41,66 & 42,65 & 39,64 & 45,94 & 50,17 & 80,37 & 74,41 & 74,89 & 95,86 & 73,79 & 18,33 & 26,27 & 24,29 \\
\hline $\mathrm{Ce}$ & 157,70 & 151,19 & 78,83 & 74,96 & 56,26 & 60,59 & 84,46 & 60,84 & 45,06 & 65,20 & 89,80 & 91,51 & 85,14 & 97,55 & 106,88 & 166,64 & 154,60 & 155,56 & 200,14 & 152,44 & 41,52 & 56,12 & 53,30 \\
\hline $\operatorname{Pr}$ & 19,23 & 18,50 & 10,26 & 9,71 & 7,00 & 7,57 & 10,42 & 7,53 & 5,88 & 8,10 & 11,70 & 11,99 & 11,07 & 12,63 & 13,82 & 21,24 & 19,88 & 20,01 & 25,64 & 19,80 & 5,62 & 7,28 & 7,17 \\
\hline $\mathrm{Nd}$ & 73,16 & 70,15 & 43,22 & 40,42 & 28,79 & 31,02 & 42,06 & 30,45 & 26,20 & 32,88 & 49,52 & 50,50 & 46,54 & 52,71 & 57,58 & 85,80 & 81,01 & 81,56 & 104,51 & 80,71 & 24,63 & 30,53 & 30,96 \\
\hline $\mathrm{Sm}$ & 15,14 & 14,49 & 9,48 & 8,86 & 6,36 & 6,77 & 8,78 & 6,54 & 6,50 & 7,02 & 10,88 & 11,10 & 10,24 & 11,31 & 12,35 & 17,52 & 16,64 & 16,90 & 21,69 & 16,70 & 5,99 & 6,99 & 7,17 \\
\hline $\mathrm{Eu}$ & 4,04 & 3,89 & 2,94 & 2,78 & 1,99 & 2,08 & 2,65 & 2,04 & 2,11 & 2,20 & 3,35 & 3,39 & 3,14 & 3,41 & 3,74 & 5,11 & 4,74 & 4,77 & 6,13 & 4,72 & 1,98 & 2,28 & 2,30 \\
\hline $\mathrm{Gd}$ & 12,45 & 11,93 & 8,49 & 7,87 & 5,88 & 6,10 & 7,61 & 5,87 & 6,34 & 6,30 & 9,43 & 9,74 & 8,81 & 9,73 & 10,62 & 14,75 & 14,23 & 14,37 & 18,47 & 14,27 & 5,86 & 6,43 & 6,77 \\
\hline $\mathrm{Tb}$ & 1,95 & 1,88 & 1,23 & 1,14 & 0,86 & 0,90 & 1,07 & 0,84 & 0,92 & 0,92 & 1,32 & 1,36 & 1,24 & 1,35 & 1,46 & 2,09 & 2,00 & 2,03 & 2,60 & 2,01 & 0,88 & 0,95 & 1,00 \\
\hline Dy & 11,28 & 10,84 & 6,83 & 6,27 & 4,87 & 5,03 & 5,85 & 4,64 & 5,12 & 5,05 & 7,13 & 7,28 & 6,65 & 7,14 & 7,78 & 11,43 & 10,86 & 10,99 & 14,08 & 10,90 & 5,04 & 5,34 & 5,62 \\
\hline Ho & 2,13 & 2,05 & 1,25 & 1,13 & 0,90 & 0,93 & 1,06 & 0,84 & 0,93 & 0,92 & 1,26 & 1,29 & 1,17 & 1,25 & 1,36 & 2,08 & 1,97 & 1,98 & 2,55 & 1,97 & 0,94 & 0,99 & 1,03 \\
\hline $\mathrm{Er}$ & 5,75 & 5,52 & 3,11 & 2,83 & 2,27 & 2,36 & 2,59 & 2,11 & 2,35 & 2,32 & 3,05 & 3,12 & 2,85 & 3,00 & 3,27 & 5,20 & 4,91 & 4,96 & 6,35 & 4,90 & 2,38 & 2,49 & 2,62 \\
\hline $\mathrm{Tm}$ & 0,82 & 0,78 & 0,41 & 0,37 & 0,30 & 0,32 & 0,34 & 0,28 & 0,30 & 0,31 & 0,39 & 0,40 & 0,37 & 0,38 & 0,42 & 0,68 & 0,65 & 0,65 & 0,83 & 0,64 & 0,32 & 0,33 & 0,34 \\
\hline $\mathrm{Yb}$ & 5,29 & 5,12 & 2,45 & 2,21 & 1,84 & 1,95 & 2,08 & 1,69 & 1,87 & 1,87 & 2,33 & 2,35 & 2,16 & 2,26 & 2,45 & 4,15 & 3,89 & 3,93 & 5,01 & 3,91 & 1,94 & 2,03 & 2,11 \\
\hline Lu & 0,77 & 0,73 & 0,34 & 0,31 & 0,25 & 0,27 & 0,29 & 0,23 & 0,26 & 0,26 & 0,32 & 0,32 & 0,29 & 0,31 & 0,33 & 0,58 & 0,55 & 0,54 & 0,70 & 0,53 & 0,27 & 0,29 & 0,30 \\
\hline$(\mathrm{La} / \mathrm{Sm})_{\mathrm{N}}$ & 3,37 & 3,36 & 2,48 & 2,52 & 2,77 & 2,82 & 3,05 & 2,95 & 1,97 & 2,93 & 2,47 & 2,48 & 2,50 & 2,62 & 2,62 & 2,96 & 2,89 & 2,86 & 2,85 & 2,85 & 1,97 & 2,42 & 2,19 \\
\hline Cr ppm & 2,20 & 4,49 & 126,07 & 162,09 & 476,42 & 400,09 & 362,08 & 423,50 & - & 440,35 & 130,82 & 143,12 & 126,59 & 59,13 & 56,93 & 0,26 & 1,87 & 1,46 & 1,70 & 2,08 & 262,93 & 75,86 & 64,87 \\
\hline
\end{tabular}




\begin{tabular}{|c|c|c|c|c|c|c|c|c|c|c|c|c|c|c|c|c|c|c|c|c|c|c|c|}
\hline 0 & 1,47 & 1,37 & 36,09 & 41,02 & 63,53 & 50,15 & 48,34 & 51,67 & 60,47 & 57,25 & 36,78 & 38,58 & 31,76 & 29,17 & 30,91 & 9,45 & 13,31 & 13,26 & 17,36 & 11,13 & 40,64 & 49,47 & 36,21 \\
\hline $\mathrm{Ni}$ & 1,46 & 1,85 & 65,00 & 94,43 & 393,82 & 229,60 & 222,78 & 300,22 & - & 333,61 & 95,41 & 107,83 & 88,88 & 55,10 & 52,79 & 0,41 & 0,82 & 0,63 & 0,93 & 0,93 & 77,91 & 59,18 & 33,78 \\
\hline $\mathrm{Cu}$ & 3,38 & 3,23 & 54,25 & 58,35 & 45,59 & 47,43 & 40,30 & 44,22 & 44,22 & 47,67 & 41,11 & 43,41 & 38,66 & 37,00 & 40,53 & 3,73 & 5,20 & 5,46 & 7,12 & 5,65 & 49,42 & 84,56 & 58,47 \\
\hline-1 & 191,87 & 182,77 & 109,51 & 107,92 & 111,98 & 105,21 & 119,57 & 105,18 & 121,35 & 114,12 & 116,39 & 121,11 & 105,32 & 112,60 & 119,91 & 175,66 & 157,11 & 158,74 & 207,88 & 155,96 & 105,77 & 187,36 & 116,09 \\
\hline b & 69,44 & 66,45 & 23,91 & 21,05 & 17,49 & 20,00 & 27,81 & 17,76 & 15,07 & 20,78 & 26,21 & 27,54 & 25,84 & 30,23 & 33,17 & 32,34 & 31,78 & 30,58 & 39,42 & 34,90 & 9,94 & 12,27 & 8,32 \\
\hline & 267,63 & 255,76 & 710,29 & 700,30 & 528,86 & 528,59 & 703,93 & 571,43 & 472,35 & 585,51 & 752,72 & 764,61 & 784,33 & 741,27 & 806,61 & 533,50 & 502,60 & 501,30 & 643,29 & 500,59 & 468,80 & 454,56 & 550,24 \\
\hline & 54,98 & 52,68 & 31,03 & 27,89 & 22,17 & 23,21 & 26,18 & 21,01 & 23,53 & 22,93 & 31,58 & 32,01 & 29,13 & 31,27 & 33,70 & 51,77 & 49,17 & 49,42 & 63,34 & 48,96 & 23,17 & 24,09 & 25,69 \\
\hline & 1002,4 & 966,74 & 325,05 & 296,95 & 202,66 & 210,43 & 288,47 & 213,02 & 194,10 & 228,42 & 347,54 & 358,80 & 330,14 & 388,92 & 418,51 & 519,81 & 495,00 & 499,29 & 640,05 & 481,74 & 176,30 & 206,85 & 222,49 \\
\hline & 84,23 & 80,48 & 36,25 & 34,99 & 26,81 & 29,54 & 40,38 & 28,92 & 19,49 & 31,11 & 40,75 & 41,74 & 38,51 & 43,34 & 46,93 & 58,17 & 53,20 & 53,19 & 68,47 & 51,36 & 19,14 & 24,36 & 20,93 \\
\hline & 818,14 & 779,87 & 332,82 & 310,27 & 265,92 & 288,20 & 399,78 & 286,42 & 167,08 & 304,38 & 363,65 & 369,60 & 347,10 & 393,68 & 431,10 & 647,69 & 567,46 & 572,29 & 733,71 & 562,94 & 147,19 & 225,33 & 181,22 \\
\hline $\mid Y$ & 18,23 & 18,35 & 10,48 & 10,65 & 9,14 & 9,07 & 11,02 & 10,14 & 8,25 & 9,96 & 11,00 & 11,21 & 11,33 & 12,44 & 12,42 & 10,04 & 10,07 & 10,10 & 10,11 & 9,84 & 7,61 & 8,59 & 8,66 \\
\hline
\end{tabular}

The analyses were made in the interior of the sample by Induced Coupled Plasma Mass Spectrometer (IC-PMS) at the University of Kiel (Geoscience Department)

and at the Centre de Recherche Pétrografique et Géochimique (Nancy, France) under the supervision of J. Morel (* and duplicated analyse=d). The analitical method and accuracy

are found in Govindaraju, (1989) and Garbe-Shönberg, (1993). T = trachyte, TA = trachy-andesite, TB = trachybasalt, alk.B. = alkali basalt, picr. B.= picritic basalt, T- and

E-MORB = Transitional \& Enriched Mid Ocean Ridge Basalt. n.d. = not determined, $(-$ ) = limit of detection, LOI = volatile lost on ignition

The sample numbers are designated by the prefix PN (Polynaut, Nautile, Table 1) and PNDR to indicate submersible dives and dredge stations respectively.

Samples 3-05 and 3-11 contain up to 15\% olivine phenocrysts. 
Table 3 (continued)

\begin{tabular}{|c|c|c|c|c|c|c|c|c|c|c|c|c|c|c|c|c|c|c|}
\hline Type & TB & TB & TB & $\mathrm{T}$ & $\mathrm{T}$ & TA & T & $\mathrm{T}$ & T & T & T & $\mathrm{T}$ & $\mathrm{T}$ & TB & TB & TA & TB & TB \\
\hline & $11-03$ & $12-01$ & $12-02^{\star}$ & $13-01$ & 13-02 & $13-05^{\star}$ & $13-08^{*}$ & $13-10$ & $13-11^{*}$ & $13-11$ & $13-13^{\star}$ & $13-13$ & $13-16^{*}$ & $14-09$ & $14-10^{*}$ & $14-11$ & $14-14$ & $14-15$ \\
\hline Depth (m) & 605 & 607 & 514 & 3000 & 2914 & 2747 & 2627 & 2553 & 2546 & 2546 & 2532 & 2543 & 2546 & 1284 & 1155 & 1131 & 866 & 816 \\
\hline $\mathrm{SiO}_{2} \mathrm{Wt} \%$ & 49,86 & 49,89 & 50,64 & 63,07 & 60,16 & 57,30 & 60,22 & 60,64 & 59,47 & n.d. & 60,29 & 59,97 & 59,29 & 52,77 & 52,65 & 53,77 & 50,22 & 50,07 \\
\hline $\mathrm{Al}_{2} \mathrm{O}_{3}$ & 16,25 & 15,12 & 14,98 & 17,52 & 17,8 & 17,08 & 17,56 & 17,54 & 17,34 & n.d. & 17,56 & 17,53 & 17,27 & 15,55 & 15,79 & 14,98 & 15,95 & 15,82 \\
\hline $\mathrm{Fe}_{2} \mathrm{O}_{3} \mathrm{~T}$ & 10,46 & 10,79 & 12,95 & 5,26 & 7,82 & 8,00 & 6,72 & 6,59 & 6,68 & n.d. & 6,67 & 6,56 & 6,69 & 10,82 & 10,80 & 10,5 & 11,23 & 11,05 \\
\hline $\mathrm{Fe}_{2} \mathrm{O}_{3}$ & n.d. & n.d. & \#\#\#\# & n.d. & n.d. & \#\#\#\# & \#\#\#\# & n.d. & \#\#\#\# & n.d. & \#\#\#\# & n.d. & \#\#\#\#\# & n.d. & \#\#\#\#\# & n.d. & n.d. & n.d. \\
\hline $\mathrm{MnO}$ & 0,13 & 0,15 & 0,16 & 0,15 & 0,18 & 0,35 & 0,16 & 0,17 & 0,17 & n.d. & 0,16 & 0,17 & 0,17 & 0,17 & 0,16 & 0,16 & 0,14 & 0,14 \\
\hline MgO & 4,77 & 6,48 & 3,32 & 0,19 & 0,78 & 0,82 & 0,51 & 0,46 & 0,52 & n.d. & 0,50 & 0,44 & 0,51 & 3,04 & 2,99 & 2,77 & 5,25 & 5,14 \\
\hline $\mathrm{CaO}$ & 8,04 & 8,26 & 6,80 & 1,5 & 2,83 & 2,77 & 2,17 & 2,13 & 2,22 & n.d. & 2,22 & 2,12 & 2,22 & 6,3 & 6,35 & 5,99 & 8,1 & 8,11 \\
\hline $\mathrm{Na}_{2} \mathrm{O}$ & 3,97 & 3,92 & 4,82 & 6,61 & 5,71 & 5,75 & 6,03 & 5,78 & 6,17 & n.d. & 6,36 & 6,06 & 6,07 & 4,74 & 5,03 & 4,59 & 4,07 & 3,85 \\
\hline $\mathrm{K}_{2} \mathrm{O}$ & 1,8 & 1,69 & 1.83 & 5,43 & 4,66 & 4.74 & 5.36 & 5,4 & 5.21 & n.d. & 5.19 & 5,22 & 5.18 & 2,19 & 2.13 & 2,06 & 1,62 & 1,52 \\
\hline $\mathrm{P}_{2} \mathrm{O}_{5}$ & 0,86 & 0,71 & 0,79 & 0,07 & 0,31 & 0,26 & 0,15 & 0,18 & 0,16 & n.d. & 0,17 & 0,18 & 0,16 & 1,05 & 0,88 & 1 & 0,71 & 0,71 \\
\hline LOI & 0,84 & 0,67 & 0,85 & 0,26 & 0,84 & 2,19 & 0,62 & 1,43 & 1,42 & n.d. & 0,25 & 0,24 & 1,97 & 1,08 & 0,82 & 1,81 & 0,33 & 0,47 \\
\hline Total & 100,61 & 100,77 & 99,91 & 100,33 & 101,84 & 100,00 & 100,01 & 100,84 & 100,00 & n.d. & 100 & 99 & 100 & 100,02 & 99,91 & 99,87 & 100,71 & 99,98 \\
\hline $\mathrm{Na}_{2} \mathrm{O}+\mathrm{K}_{2} \mathrm{O}$ & 5,77 & 5,61 & 6,65 & 12,04 & 10,37 & 10,49 & 11,39 & 11,18 & 11,38 & n.d. & 11,55 & 11,28 & 11,25 & 6,93 & 7,16 & 6,65 & 5,69 & 5,37 \\
\hline La ppm & 43,18 & 44,80 & n.d. & 122,38 & 99,56 & n.d. & n.d. & 103,52 & n.d. & 101,74 & 107,26 & n.d. & n.d. & 54,37 & n.d. & 58,79 & 37,26 & 38,73 \\
\hline $\mathrm{Ce}$ & 92,09 & 91,37 & n.d. & 219,44 & 188,47 & n.d. & n.d. & 195,48 & n.d. & 205,50 & 201,84 & n.d. & n.d. & 122,65 & n.d. & 132,99 & 83,75 & 87,06 \\
\hline $\operatorname{Pr}$ & 12,01 & 11,28 & n.d. & 24,54 & 22,29 & n.d. & n.d. & 22,39 & n.d. & 22,06 & 23,28 & n.d. & n.d. & 15,63 & n.d. & 16,93 & 10,63 & 11,09 \\
\hline $\mathrm{Nd}$ & 50,36 & 45,15 & n.d. & 83,17 & 81,20 & n.d. & n.d. & 80,09 & n.d. & 79,57 & 83,19 & n.d. & n.d. & 66,81 & n.d. & 72,57 & 45,39 & 47,19 \\
\hline Sm & 10,95 & 9,34 & n.d. & 14,76 & 15,15 & n.d. & n.d. & 14,74 & n.d. & 14,51 & 15,22 & n.d. & n.d. & 15,03 & n.d. & 16,20 & 10,07 & 10,51 \\
\hline Eu & 3,32 & 2,82 & n.d. & 2,11 & 4,20 & n.d. & n.d. & 3,59 & n.d. & 3,59 & 3,75 & n.d. & n.d. & 4,37 & n.d. & 4,78 & 3,14 & 3,25 \\
\hline Gd & 9,42 & 8,10 & n.d. & 11,71 & 12,30 & n.d. & n.d. & 11,82 & n.d. & 12,15 & 12,33 & n.d. & n.d. & 13,99 & n.d. & 14,98 & 9,26 & 9,63 \\
\hline $\mathrm{Tb}$ & 1,32 & 1,14 & n.d. & 1,83 & 1,84 & n.d. & n.d. & 1,80 & n.d. & 1,80 & 1,86 & n.d. & n.d. & 2,00 & n.d. & 2,17 & 1,30 & 1,37 \\
\hline Dy & 7,00 & 6,20 & n.d. & 10,65 & 10,45 & n.d. & n.d. & 10,30 & n.d. & 10,16 & 10,59 & n.d. & n.d. & 11,06 & n.d. & 12,03 & 7,06 & 7,30 \\
\hline Ho & 1,24 & 1,11 & n.d. & 2,03 & 1,96 & n.d. & n.d. & 1,94 & n.d. & 1,89 & 2,01 & n.d. & n.d. & 2,02 & n.d. & 2,19 & 1,25 & 1,29 \\
\hline $\mathrm{Er}$ & 2,96 & 2,74 & n.d. & 5,52 & 5,16 & n.d. & n.d. & 5,17 & n.d. & 5,10 & 5,31 & n.d. & n.d. & 5,14 & n.d. & 5,59 & 3,09 & 3,22 \\
\hline Tm & 0,38 & 0,36 & n.d. & 0,81 & 0,72 & n.d. & n.d. & 0,73 & n.d. & 0,71 & 0,75 & n.d. & n.d. & 0,65 & n.d. & 0,73 & 0,39 & 0,40 \\
\hline $\mathrm{Yb}$ & 2,24 & 2,13 & n.d. & 5,39 & 4,59 & n.d. & n.d. & 4,70 & n.d. & 4,54 & 4,87 & n.d. & n.d. & 4,00 & n.d. & 4,41 & 2,37 & 2,46 \\
\hline Lu & 0,30 & 0,29 & n.d. & 0,78 & 0,65 & n.d. & n.d. & 0,67 & n.d. & 0,67 & 0,71 & n.d. & n.d. & 0,57 & n.d. & 0,61 & 0,33 & 0,34 \\
\hline$(\mathrm{La} / \mathrm{Sm})_{\mathrm{N}}$ & 2,55 & 3,10 & n.d. & 5,35 & 4,24 & n.d. & n.d. & 4,53 & n.d. & 4,53 & 4,55 & n.d. & n.d. & 2,33 & n.d. & 2,34 & 2,39 & 2,38 \\
\hline
\end{tabular}




\begin{tabular}{|c|c|c|c|c|c|c|c|c|c|c|c|c|c|c|c|c|c|c|}
\hline Cr ppm & 68,44 & 174,70 & n.d. & 0,25 & 6,17 & n.d. & n.d. & 0,99 & n.d. & - & 3,92 & n.d. & n.d. & - & n.d. & & & - \\
\hline Co & 29,71 & 37,36 & n.d. & 0,35 & 2,77 & n.d. & n.d. & 1,40 & n.d. & 11,36 & 1,34 & n.d. & n.d. & 18,92 & n.d. & 19,82 & 33,60 & 34,24 \\
\hline $\mathrm{Ni}$ & 57,01 & 109,68 & n.d. & 0,36 & 1,44 & n.d. & n.d. & 2,01 & n.d. & - & 1,48 & n.d. & n.d. & - & n.d. & - & - & - \\
\hline $\mathrm{Cu}$ & 34,98 & 40,86 & n.d. & 2,70 & 6,06 & n.d. & n.d. & 4,19 & n.d. & 10,42 & 3,94 & n.d. & n.d. & 11,43 & n.d. & 12,66 & 33,25 & 34,27 \\
\hline $\mathrm{Zn}$ & 114,13 & 105,41 & n.d. & 189,27 & 207,25 & n.d. & n.d. & 187,86 & n.d. & 163,28 & 181,76 & n.d. & n.d. & 151,53 & n.d. & 155,74 & 118,93 & 130,05 \\
\hline $\mathrm{Rb}$ & 29,23 & 27,60 & n.d. & 107,46 & 71,23 & n.d. & n.d. & 78,24 & n.d. & 102,14 & 99,62 & n.d. & n.d. & 44,78 & n.d. & 48,27 & 31,77 & 32,71 \\
\hline $\mathrm{Sr}$ & 741,90 & 726,70 & n.d. & 51,71 & 353,58 & n.d. & n.d. & 208,51 & n.d. & 203,46 & 215,65 & n.d. & n.d. & 569,81 & n.d. & 611,28 & 640,76 & 657,06 \\
\hline Y & 30,44 & 27,79 & n.d. & 50,80 & 49,65 & n.d. & n.d. & 49,29 & n.d. & 44,02 & 50,22 & n.d. & n.d. & 49,97 & n.d. & 53,63 & 30,86 & 31,95 \\
\hline $\mathrm{Zr}$ & 363,69 & 312,67 & n.d. & 934,26 & 780,83 & n.d. & n.d. & 839,05 & n.d. & 790,25 & 894,53 & n.d. & n.d. & 502,05 & n.d. & 538,02 & 345,15 & 356,23 \\
\hline $\mathrm{Nb}$ & 41,54 & 41,26 & n.d. & 111,78 & 90,35 & n.d. & n.d. & 96,79 & n.d. & 90,80 & 101,10 & n.d. & n.d. & 46,80 & n.d. & 50,77 & 35,90 & 37,56 \\
\hline $\mathrm{Ba}$ & 374,55 & 414,27 & n.d. & 463,26 & 1160,1 & n.d. & n.d. & 1198,8 & n.d. & 1199,4 & 1252 & n.d. & n.d. & 436,23 & n.d. & 469,91 & 322,10 & 331,26 \\
\hline $\mathrm{Zr} / \mathrm{Y}$ & 11,95 & 11,25 & n.d. & 18,39 & 15,73 & n.d. & n.d. & 17,02 & n.d. & 17,95 & 17,81 & n.d. & n.d. & 10,05 & n.d. & 10,03 & 11,18 & 11,15 \\
\hline
\end{tabular}


Table 3 (continued)

\begin{tabular}{|c|c|c|c|c|c|c|c|c|c|c|c|c|c|c|c|}
\hline Type & $\mathrm{T}$ & TB & TB & TB & TB & Sub alk.B. & T-MORB & TA & TA & TA & alk.B. & alk.B & TA & TA & T-MORB \\
\hline sample & D 1-01 & D 2-1 & D 2-1d & D 3-01 & D 5-1 & D 6-1 & D $7-2$ & D 11-1 & D 12-1 & D 13-3 & D14-1 & D14-1d & D11-7* & D11-8 & 80DS2 \\
\hline Depth (m) & 3100 & 3400 & 3400 & 3000 & 3400 & 2900 & 2800 & 3400 & 3000 & 2700 & 1895 & 1895 & 3450 & 3450 & 2477 \\
\hline $\mathrm{SiO}_{2} \mathrm{Wt} \%$ & 59,58 & 50,43 & n.d. & 51,86 & 51,4 & 48,5 & 47,78 & 57 & 55,91 & 57,61 & 49,03 & 48,99 & 57,40 & 57,59 & 50,2 \\
\hline $\mathrm{Al}_{2} \mathrm{O}_{3}$ & 17,33 & 14,86 & n.d. & 16,97 & 17,03 & 14,95 & 19,04 & 16,32 & 16,38 & 17,34 & 15,66 & 15,83 & 16,34 & 17,39 & 15,15 \\
\hline $\mathrm{Fe}_{2} \mathrm{O}_{3} \mathrm{~T}$ & 6,65 & 12,05 & n.d. & 11,03 & 11,24 & 11,41 & 8,97 & 8,12 & 9,84 & 7,82 & 10,86 & 10,72 & 8,40 & 8,11 & 11,03 \\
\hline $\mathrm{Fe}_{2} \mathrm{O}_{3}$ & n.d. & n.d. & n.d. & n.d. & n.d. & n.d. & n.d. & n.d. & n.d. & n.d. & n.d. & \#\#\#\#\# & \#\#\#\#\# & \#\#\#\#\# & n.d. \\
\hline MnO & 0,17 & 0,16 & n.d. & 0,19 & 0,19 & 0,14 & 0,13 & 0,23 & 0,22 & 0,18 & 0,14 & 0,13 & 0,23 & 0,18 & 0,18 \\
\hline $\mathrm{MgO}$ & 0,5 & 3,69 & n.d. & 2,52 & 2,46 & 7,31 & 5,5 & 0,21 & 1,36 & 0,9 & 5,29 & 5,59 & 0,24 & 0,92 & 7,27 \\
\hline $\mathrm{CaO}$ & 2,29 & 6,65 & n.d. & 5,2 & 5,25 & 9,37 & 12,32 & 2,13 & 3,85 & 2,86 & 10,07 & 10,12 & 2,21 & 2,98 & 12,38 \\
\hline $\mathrm{Na}_{2} \mathrm{O}$ & 5,86 & 4,03 & n.d. & 5,33 & 5,25 & 3,1 & 2,76 & 6,58 & 4,99 & 5,5 & 3,22 & 3,36 & 6,57 & 5,90 & 2,55 \\
\hline $\mathrm{K}_{2} \mathrm{O}$ & 5,04 & 2,12 & n.d. & 3,18 & 3,02 & 1,02 & 0,16 & 5,2 & 3,73 & 4,58 & 1,29 & 1.28 & 5.24 & 4.57 & 0,23 \\
\hline $\mathrm{P}_{2} \mathrm{O}_{5}$ & 0,18 & 1,13 & n.d. & 1,14 & 1,11 & 0,44 & 0,08 & 0,12 & 0,54 & 0,34 & 0,52 & 0,46 & 0,11 & 0,30 & 0,12 \\
\hline LOI & 0,68 & 1,35 & n.d. & 0,59 & 0,36 & 0,57 & 2,41 & 2,73 & 1,41 & 1,31 & 0,51 & 0,56 & 2,82 & 1,30 & 0,41 \\
\hline Total & 98,85 & 99,32 & n.d. & 99,81 & 99,1 & 99,59 & 100,27 & 99,01 & 99,41 & 99,2 & 99,81 & 100,14 & 99,94 & 100,01 & 100,2 \\
\hline $\mathrm{Na}_{2} \mathrm{O}+\mathrm{K}_{2} \mathrm{O}$ & 10,90 & 6,15 & n.d. & 8,51 & 8,27 & 4,12 & 2,92 & 11,78 & 8,72 & 10,08 & 4,51 & 4,64 & 11,81 & 10,47 & 2,78 \\
\hline La ppm & 102,35 & 52,57 & 56,69 & 82,99 & 88,28 & 21,33 & 1,63 & 112,54 & 89,08 & 92,52 & 27,22 & 28,08 & n.d. & n.d. & 3,3 \\
\hline $\mathrm{Ce}$ & 195,57 & 111,00 & 119,79 & 165,54 & 176,19 & 48,02 & 5,82 & 223,56 & 178,43 & 176,32 & 60,16 & 62,16 & n.d. & n.d. & n.d. \\
\hline $\operatorname{Pr}$ & 23,14 & 14,43 & 15,54 & 20,46 & 21,64 & 6,53 & 1,16 & 27,58 & 22,09 & 20,67 & 7,98 & 8,45 & n.d. & n.d. & n.d. \\
\hline $\mathrm{Nd}$ & 84,03 & 59,74 & 64,55 & 79,69 & 83,73 & 28,42 & 6,82 & 103,76 & 85,30 & 75,61 & 34,02 & 36,22 & n.d. & n.d. & 8 \\
\hline Sm & 16,15 & 12,90 & 13,93 & 15,60 & 16,23 & 6,81 & 2,51 & 20,27 & 16,86 & 14,18 & 7,74 & 7,57 & n.d. & n.d. & n.d. \\
\hline $\mathrm{Eu}$ & 4,44 & 3,69 & 3,99 & 4,47 & 4,67 & 2,22 & 1,00 & 5,17 & 5,09 & 3,96 & 2,41 & 2,59 & n.d. & n.d. & 1,3 \\
\hline $\mathrm{Gd}$ & 13,06 & 11,29 & 12,17 & 12,89 & 13,63 & 6,46 & 3,33 & 16,48 & 14,21 & 11,52 & 7,05 & 7,44 & n.d. & n.d. & n.d. \\
\hline $\mathrm{Tb}$ & 1,99 & 1,57 & 1,70 & 1,82 & 1,90 & 0,95 & 0,60 & 2,50 & 2,08 & 1,73 & 1,02 & 1,01 & n.d. & n.d. & n.d. \\
\hline Dy & 11,34 & 8,53 & 9,20 & 9,78 & 10,20 & 5,37 & 3,97 & 14,18 & 11,45 & 9,68 & 5,62 & 5,59 & n.d. & n.d. & 5,3 \\
\hline Ho & 2,14 & 1,52 & 1,65 & 1,77 & 1,84 & 0,99 & 0,83 & 2,62 & 2,11 & 1,81 & 1,01 & 0,98 & n.d. & n.d. & n.d. \\
\hline $\mathrm{Er}$ & 5,65 & 3,76 & 4,08 & 4,35 & 4,54 & 2,47 & 2,33 & 6,80 & 5,36 & 4,73 & 2,50 & 2,47 & n.d. & n.d. & 2,7 \\
\hline Tm & 0,79 & 0,49 & 0,53 & 0,58 & 0,60 & 0,32 & 0,34 & 0,94 & 0,72 & 0,66 & 0,33 & 0,33 & n.d. & n.d. & n.d. \\
\hline $\mathrm{Yb}$ & 5,02 & 2,96 & 3,19 & 3,47 & 3,60 & 1,99 & 2,19 & 5,84 & 4,46 & 4,17 & 1,98 & 2,07 & n.d. & n.d. & n.d. \\
\hline Lu & 0,72 & 0,41 & 0,44 & 0,48 & 0,50 & 0,27 & 0,32 & 0,83 & 0,63 & 0,59 & 0,27 & 0,27 & n.d. & n.d. & 2,1 \\
\hline$(\mathrm{La} / \mathrm{Sm})_{\mathrm{N}}$ & 4,09 & 2,63 & 2,63 & 3,44 & 3,51 & 2,02 & 0,42 & 3,58 & 3,41 & 4,21 & 2,27 & 2,40 & n.d. & n.d. & n.d. \\
\hline
\end{tabular}




\begin{tabular}{|c|c|c|c|c|c|c|c|c|c|c|c|c|c|c|c|}
\hline $\mathrm{Cr} \mathrm{ppm}$ & 1,94 & 0,42 & 1,03 & 0,18 & 0,31 & 312,66 & 236,38 & 0,58 & 0,21 & 2,46 & 212,76 & 233,00 & n.d. & n.d. & 305,00 \\
\hline Co & 1,10 & 25,40 & 27,19 & 13,64 & 15,54 & 48,81 & 48,15 & 0,75 & 2,54 & 2,90 & 35,35 & 34,12 & n.d. & n.d. & 47,00 \\
\hline $\mathrm{Ni}$ & 1,99 & 3,19 & 3,50 & 1,27 & 1,66 & 167,66 & 117,03 & 1,12 & 0,26 & 0,39 & 69,18 & 72,68 & n.d. & n.d. & n.d. \\
\hline $\mathrm{Cu}$ & 3,43 & 15,18 & 16,28 & 5,21 & 7,79 & 37,53 & 78,44 & 4,29 & 2,67 & 3,31 & 33,26 & 35,80 & n.d. & n.d. & n.d. \\
\hline $\mathrm{Zn}$ & 189,95 & 138,11 & 152,32 & 176,61 & 198,99 & 110,77 & 89,72 & 249,45 & 203,86 & 182,47 & 102,39 & 118,40 & n.d. & n.d. & n.d. \\
\hline $\mathrm{Rb}$ & 76,46 & 30,35 & 32,57 & 47,14 & 56,00 & 12,91 & 2,92 & 81,48 & 38,12 & 64,66 & 16,73 & 16,31 & n.d. & n.d. & 7,00 \\
\hline Sr & 265,26 & 500,12 & 539,54 & 611,26 & 647,34 & 523,94 & 144,97 & 53,77 & 459,46 & 352,53 & 547,92 & 516,89 & n.d. & n.d. & 115,00 \\
\hline$Y$ & 53,64 & 38,55 & 41,25 & 43,98 & 46,20 & 24,49 & 21,10 & 64,69 & 52,90 & 46,62 & 24,92 & 25,94 & n.d. & n.d. & 34,00 \\
\hline $\mathrm{Zr}$ & 819,36 & 374,81 & 402,10 & 519,69 & 562,44 & 213,09 & 62,39 & 783,47 & 605,94 & 721,25 & 243,93 & 257,19 & n.d. & n.d. & 77,00 \\
\hline $\mathrm{Nb}$ & 94,34 & 41,08 & 43,93 & 66,14 & 71,75 & 20,98 & 0,70 & 131,63 & 73,54 & 83,47 & 26,05 & 24,14 & n.d. & n.d. & 1,50 \\
\hline $\mathrm{Zr} / \mathrm{Y}$ & 15,28 & 9,72 & 9,75 & 11,82 & 12,17 & 8,70 & 2,96 & 12,11 & 11,45 & 15,47 & 9,79 & 9,91 & n.d. & n.d. & 2,26 \\
\hline
\end{tabular}

$\mathrm{D}=$ Dredged samples from the Pictcairn region $($ Table 1 PNDR $=\mathrm{D})$.

Sample 80DS2 is a pillow lava fragment with partially palagonatized glassy chilled margin (Binard et al., 1989). DR = dreged samples 80DS2 = aphyric pillow lava with glassy (partially palagonatized) indurated sediment coating, from Young volcano (Binard et al., 1989). 
Table 4 Microprobe analyses of glassy margins recovered by submersible from the Pitcairn hotspot region.

Type alk.B. alk.B. picr.B. TA $\begin{array}{lllllllllllll} & \text { alk.B. TB } & \text { alk.B. } & \text { TA } & \text { TB } & \text { TA } & \text { TA } & \text { TA } & \text { TA } & \text { TA } & \text { T } & \text { T }\end{array}$

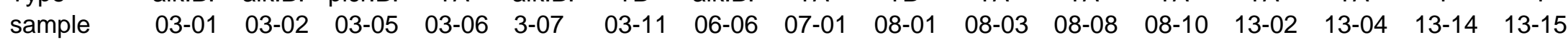
$\begin{array}{llllllllllllllllll}\text { depth }(\mathrm{m}) & 2568 & 2568 & 2408 & 2376 & 2276 & 1957 & 712 & 3700 & 3131 & 2951 & 2585 & 2511 & 2914 & 2896 & 2532 & 2566\end{array}$

\begin{tabular}{|c|c|c|c|c|c|c|c|c|c|c|c|c|c|c|c|c|}
\hline er. & 6 & 5 & 3 & 3 & 3 & 3 & 3 & 4 & 3 & 5 & 3 & 3 & 3 & 3 & 3 & 5 \\
\hline $\mathrm{SiO}_{2} \mathrm{Wt} \%$ & 8,16 & 7,90 & 3,27 & 4,87 & 3,55 & 9,58 & 8,36 & 56,39 & 52,47 & 54,12 & 55,04 & 55,19 & 58,93 & , & 1,28 & 0,82 \\
\hline $\mathrm{IO}_{2}$ & 2,99 & 2,94 & 2,99 & 1,52 & 16 & 51 & 16 & 86 & 77 & 1,98 & 2,09 & 1,96 & 0,67 & 74 &, 50 & 0,46 \\
\hline 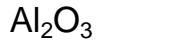 & 16,1 & 6,03 & 6,03 & 16,99 & & & & & & & & & & & & 7,04 \\
\hline & & & & & & & & & & & & & & & & 62 \\
\hline & & & & & & & & & & & & & & & & 18 \\
\hline & & & & & & & & & & & & & & & & 45 \\
\hline $\mathrm{a}$ & & & 1 & & & & & & & , & & & & & & 02 \\
\hline $\mathrm{a}_{2} \mathrm{O}$ & & 2 & 238 & 4,65 & 3,81 & & & 3,8 & 3,70 & 4,72 & & 4 & & & 2 & ,33 \\
\hline${ }_{2} \mathrm{O}$ & & & & & 1,48 & 1 & & & & & & & & & & 5,49 \\
\hline 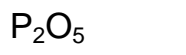 & 0,61 & 0,61 & & & - & - & & & 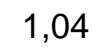 & & 1, & & 0,26 & & 6 & 0,14 \\
\hline $\mathrm{O}_{3}$ & - & - & & & - & - & & & & & & & 0,06 & & 1 & 0,01 \\
\hline otal &, 55 & 6,22 & 98,63 & 97,28 & 97,87 & 8,79 & 98,41 & 32 & 98,15 & 98,45 & 97,86 & 98,58 & 98,05 & 97,02 & 5,86 & 7,56 \\
\hline$/ \mathrm{Ti}$ & 0,67 & 0,78 & 0,64 & 3,26 & 0,65 & 0,68 & 0,69 & 2 & 1,67 & 1,93 & 1,77 & 1,89 & 10,11 & 9,35 & 13,10 & 16,62 \\
\hline $\mathrm{Ja}_{2} \mathrm{O}+\mathrm{K}$ & 4,65 & 4,88 & 3,76 & 8,23 & 5,29 & 5,70 & 5,14 & 7,13 & 5,83 & 7,47 & 7,03 & 7,15 & 10,43 & 10,12 & 7,62 & 10,82 \\
\hline
\end{tabular}

\begin{tabular}{|c|c|c|c|c|c|c|c|c|c|c|}
\hline Type & TB & TA & TB & TB & TA & TB & $\begin{array}{c}\text { TB } \\
\text { D02- } \\
01\end{array}$ & $\begin{array}{c}\mathrm{T} \\
\mathrm{D} 11- \\
02\end{array}$ & $\begin{array}{c}\mathrm{T} \\
\text { D11- } \\
05\end{array}$ & $\begin{array}{c}\mathrm{T} \\
\text { D13- } \\
07\end{array}$ \\
\hline & 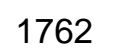 & 170 & & 1 & 1032 & & 3400 & 3400 & 3400 & 2700 \\
\hline aver & 3,0 & 3,00 & & 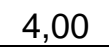 & 3,0 & & & 0 & & \\
\hline $\mathrm{SiO}_{2} \mathrm{~V}$ & 49,30 & 55,15 & 51,34 & 51,73 & 54,43 & 50,91 & 52,53 & 60,86 & 60,95 & 59,08 \\
\hline $\mathrm{TiO}_{2}$ & 3,48 & 2,18 & 3,1 & 3,1 & 2,60 & 3,52 & 2,87 & 0,23 & 0,22 & 0,78 \\
\hline $\mathrm{Al}_{2} \mathrm{O}_{3}$ & ,73 & 15,19 & 14,87 & 16,12 & 14,52 & 15,11 & 14, & 17,16 & 17,03 & 17,58 \\
\hline eO &, 0 & 9,60 & 9 & 8,7 & 9,7 & 10,23 & 9,8 & 6 , & 6,48 & 6,88 \\
\hline $\mathrm{nO}$ & 14 & ,2 & 13 & 12 & 0,1 & 0 & 0,16 & ,25 &, 20 &, 26 \\
\hline $\mathrm{gO}$ & 56 & 2,63 & 5,55 & 4,72 & 2,6 & 4,27 & 3,38 & 0,15 &, 13 & D,84 \\
\hline $\mathrm{CaO}$ & 84 & 5,54 & 8,79 & 3,41 & 5,94 & 8,02 & 99 & 2,07 & ,87 & 2,91 \\
\hline & $2 \varsigma$ & 4,05 & 45 & 14 & 01 & 75 & 4,04 & 08 & ,41 & 3,22 \\
\hline
\end{tabular}




\begin{tabular}{lcccccccccc}
$\mathrm{K}_{2} \mathrm{O}$ & 1,25 & 2,61 & 0,96 & 1,66 & 2,75 & 1,70 & 2,28 & 4,35 & 4,72 & 4,28 \\
$\mathrm{P}_{2} \mathrm{O}_{5}$ & - & 0,84 & 0,46 & - & - & - & 1,29 & 0,09 & 0,04 & 0,30 \\
$\mathrm{SO}_{3}$ & - & 0,18 & 0,31 & - & - & - & 0,26 & 0,01 & 0,00 & 0,01 \\
$\mathrm{Total}$ & 97,69 & 98,21 & 98,35 & 98,78 & 96,83 & 97,65 & 98,37 & 95,07 & 95,08 & 96,13 \\
$\mathrm{~K} / \mathrm{Ti}$ & 0,50 & 1,66 & 0,42 & 0,74 & 1,47 & 0,67 & 1,10 & 26,03 & 30,09 & 7,62 \\
$\mathrm{Na}_{2} \mathrm{O}+\mathrm{K}_{2} \mathrm{O}$ & 4,55 & 6,67 & 4,40 & 5,80 & 6,76 & 5,44 & 6,33 & 7,43 & 8,13 & 7,50 \\
\hline
\end{tabular}

Microprobe analyses done with SM 50 CAMEBAX (microsonde de l'Ouest) at IFREMER (Brest). $D=$ Dredged samples from the Pictcairn region are shown in Table $1(P N D R=D)$.

The sample collected by submersible and dredge hauls have the prefix PN, and PNDR respectively. 
Table 5 Summary of volcanic rocks used to construct the lithological sequences of the Bounty volcano in the Pitcairn region

\begin{tabular}{|c|c|c|c|c|c|c|c|c|c|c|c|c|c|c|c|c|}
\hline Type & alk.B. & alk.B. & picr.B. & TA & alk.B. & TB & alk.B. & TA & TВ & $\begin{array}{c}\text { TA } \\
08-03\end{array}$ & $\begin{array}{c}\text { TA } \\
08-08\end{array}$ & $\begin{array}{c}\text { TA } \\
08-10\end{array}$ & $\begin{array}{c}\text { TA } \\
13-02\end{array}$ & $\begin{array}{c}\text { TA } \\
13-04\end{array}$ & $\begin{array}{c}\mathrm{T} \\
13-14\end{array}$ & $\frac{\mathrm{T}}{13-15}$ \\
\hline depth (m) & 2568 & 2568 & 2408 & $\begin{array}{l}23-00 \\
2376\end{array}$ & $\begin{array}{l}3-07 \\
2276\end{array}$ & $\begin{array}{l}1957-11 \\
1957\end{array}$ & 712 & $\begin{array}{l}07-01 \\
3700\end{array}$ & $\begin{array}{c}00-01 \\
3131\end{array}$ & $\begin{array}{l}00-03 \\
2951\end{array}$ & $\begin{array}{l}00-00 \\
2585\end{array}$ & $\begin{array}{l}08-10 \\
2511\end{array}$ & $\begin{array}{c}13-02 \\
2914\end{array}$ & $\begin{array}{l}13-04 \\
2896\end{array}$ & $\begin{array}{l}13-14 \\
2532\end{array}$ & $\begin{array}{r}13-15 \\
2566\end{array}$ \\
\hline aver. & 6 & 5 & 3 & 3 & 3 & 3 & 3 & 4 & 3 & 5 & 3 & 3 & 3 & 3 & 3 & 5 \\
\hline $\mathrm{SiO}_{2} \mathrm{Wt} \%$ & 48,16 & 47,90 & 48,27 & 54,87 & 48,55 & 49,58 & 48,36 & 56,39 & 52,47 & 54,12 & 55,04 & 55,19 & 58,93 & 58,41 & 61,28 & 60,82 \\
\hline $\mathrm{TiO}_{2}$ & 2,99 & 2,94 & 2,99 & 1,52 & 3,16 & 3,51 & 3,16 & 1,86 & 1,77 & 1,98 & 2,09 & 1,96 & 0,67 & 0,74 & 0,50 & 0,46 \\
\hline $\mathrm{Al}_{2} \mathrm{O}_{3}$ & 16,11 & 16,03 & 16,03 & 16,99 & 15,49 & 15,21 & 15,56 & 16,15 & 13,46 & 15,64 & 15,68 & 15,69 & 16,95 & 17,16 & 17,60 & 17,04 \\
\hline FeOT & 9,24 & 9,23 & 9,69 & 8,17 & 9,88 & 9,69 & 10,13 & 8,36 & 11,91 & 9,57 & 8,80 & 9,14 & 6,78 & 6,79 & 5,92 & 5,62 \\
\hline $\mathrm{MnO}$ & 0,17 & 0,16 & 0,19 & 0,21 & 0,17 & 0,15 & 0,13 & 0,23 & 0,17 & 0,25 & 0,14 & 0,18 & 0,19 & 0,18 & 0,18 & 0,18 \\
\hline $\mathrm{MgO}$ & 5,20 & 5,22 & 6,54 & 1,84 & 5,21 & 5,72 & 5,26 & 2,07 & 6,90 & 2,57 & 2,65 & 2,66 & 0,79 & 0,82 & 0,47 & 0,45 \\
\hline $\mathrm{CaO}$ & 9,41 & 9,24 & 10,41 & 4,54 & 10,10 & 9,10 & 9,95 & 4,75 & 4,49 & 5,56 & 5,12 & 5,28 & 2,98 & 2,77 & 2,11 & 2,02 \\
\hline $\mathrm{Na}_{2} \mathrm{O}$ & 3,19 & 3,22 & 2,38 & 4,65 & 3,81 & 3,99 & 3,56 & 3,89 & 3,70 & 4,72 & 4,37 & 4,48 & 5,51 & 5,11 & 2,92 & 5,33 \\
\hline $\mathrm{K}_{2} \mathrm{O}$ & 1,45 & 1,66 & 1,38 & 3,59 & 1,48 & 1,71 & 1,58 & 3,24 & 2,13 & 2,75 & 2,66 & 2,67 & 4,92 & 5,01 & 4,70 & 5,49 \\
\hline $\mathrm{P}_{2} \mathrm{O}_{5}$ & 0,61 & 0,61 & 0,56 & 0,77 & - & - & 0,53 & 0,78 & 1,04 & 1,19 & 1,16 & 1,18 & 0,26 & - & 0,16 & 0,14 \\
\hline $\mathrm{SO}_{3}$ & - & - & 0,14 & 0,14 & - & - & 0,10 & 0,10 & 0,12 & 0,10 & 0,15 & 0,15 & 0,06 & - & 0,01 & 0,01 \\
\hline Total & 96,55 & 96,22 & 98,63 & 97,28 & 97,87 & 98,79 & 98,41 & 97,82 & 98,15 & 98,45 & 97,86 & 98,58 & 98,05 & 97,02 & 95,86 & 97,56 \\
\hline $\mathrm{K} / \mathrm{Ti}$ & 0,67 & 0,78 & 0,64 & 3,26 & 0,65 & 0,68 & 0,69 & 2,42 & 1,67 & 1,93 & 1,77 & 1,89 & 10,11 & 9,35 & 13,10 & 16,62 \\
\hline $\mathrm{Na}_{2} \mathrm{O}+\mathrm{K}_{2} \mathrm{O}$ & 4,65 & 4,88 & 3,76 & 8,23 & 5,29 & 5,70 & 5,14 & 7,13 & 5,83 & 7,47 & 7,03 & 7,15 & 10,43 & 10,12 & 7,62 & 10,82 \\
\hline Type & TB & TA & TB & TB & TA & TB & TB & $\mathrm{T}$ & $\mathrm{T}$ & $\mathrm{T}$ & & & & & & \\
\hline sample & $14-03$ & 14-04 & $14-06$ & $14-08$ & $14-12$ & $14-13$ & $\begin{array}{c}\text { D02- } \\
01\end{array}$ & $\begin{array}{c}\text { D11- } \\
02\end{array}$ & $\begin{array}{c}\text { D11- } \\
05\end{array}$ & $\begin{array}{c}\text { D13- } \\
07\end{array}$ & & & & & & \\
\hline depth (m) & 1762 & 1705 & 1614 & 1404 & 1032 & 950 & 3400 & 3400 & 3400 & 2700 & & & & & & \\
\hline aver. & 3,00 & 3,00 & 4,00 & 4,00 & 3,00 & 2,00 & 5,00 & 6,00 & 5,00 & 3,00 & & & & & & \\
\hline $\mathrm{SiO}_{2} \mathrm{Wt} \%$ & 49,30 & 55,15 & 51,34 & 51,73 & 54,43 & 50,91 & 52,53 & 60,86 & 60,95 & 59,08 & & & & & & \\
\hline $\mathrm{TiO}_{2}$ & 3,48 & 2,18 & 3,13 & 3,12 & 2,60 & 3,52 & 2,87 & 0,23 & 0,22 & 0,78 & & & & & & \\
\hline $\mathrm{Al}_{2} \mathrm{O}_{3}$ & 14,73 & 15,19 & 14,87 & 16,12 & 14,52 & 15,11 & 14,73 & 17,16 & 17,03 & 17,58 & & & & & & \\
\hline FeOT & 10,08 & 9,60 & 9,38 & 8,72 & 9,71 & 10,23 & 9,83 & 6,77 & 6,48 & 6,88 & & & & & & \\
\hline $\mathrm{MnO}$ & 0,14 & 0,21 & 0,13 & 0,12 & 0,17 & 0,11 & 0,16 & 0,25 & 0,20 & 0,26 & & & & & & \\
\hline $\mathrm{MgO}$ & 5,56 & 2,63 & 5,55 & 4,72 & 2,62 & 4,27 & 3,38 & 0,15 & 0,13 & 0,84 & & & & & & \\
\hline $\mathrm{CaO}$ & 9,84 & 5,54 & 8,79 & 8,41 & 5,94 & 8,02 & 6,99 & 2,07 & 1,87 & 2,91 & & & & & & \\
\hline $\mathrm{Na}_{2} \mathrm{O}$ & 3,29 & 4,05 & 3,45 & 4,14 & 4,01 & 3,75 & 4,04 & 3,08 & 3,41 & 3,22 & & & & & & \\
\hline
\end{tabular}




\begin{tabular}{lcccccccccc}
$\mathrm{K}_{2} \mathrm{O}$ & 1,25 & 2,61 & 0,96 & 1,66 & 2,75 & 1,70 & 2,28 & 4,35 & 4,72 & 4,28 \\
$\mathrm{P}_{2} \mathrm{O}_{5}$ & - & 0,84 & 0,46 & - & - & - & 1,29 & 0,09 & 0,04 & 0,30 \\
$\mathrm{SO}_{3}$ & - & 0,18 & 0,31 & - & - & - & 0,26 & 0,01 & 0,00 & 0,01 \\
$\mathrm{Total}$ & 97,69 & 98,21 & 98,35 & 98,78 & 96,83 & 97,65 & 98,37 & 95,07 & 95,08 & 96,13 \\
$\mathrm{~K} / \mathrm{Ti}$ & 0,50 & 1,66 & 0,42 & 0,74 & 1,47 & 0,67 & 1,10 & 26,03 & 30,09 & 7,62 \\
$\mathrm{Na}_{2} \mathrm{O}+\mathrm{K}_{2} \mathrm{O}$ & 4,55 & 6,67 & 4,40 & 5,80 & 6,76 & 5,44 & 6,33 & 7,43 & 8,13 & 7,50 \\
\hline
\end{tabular}

Microprobe analyses done with SM 50 CAMEBAX (microsonde de l'Ouest) at IFREMER (Brest). $\mathrm{D}=$ Dredged samples from the Pictcairn region are shown in Table $1($ PNDR $=\mathrm{D})$.

The sample collected by submersible and dredge hauls have the prefix PN, and PNDR respectively. 